\title{
Synthetic antenna functioning as light harvester in the whole visible region for enhanced hybrid photosynthetic reaction centers.
}

Omar Hassan Omar $^{\dagger}$, Simona la Gatta ${ }^{\S}$, Rocco Roberto Tangorra ${ }^{\S, \#}$, Francesco Milano ${ }^{\ddagger}$, Roberta Ragni ${ }^{\S}$, Alessandra Operamolla ${ }^{\S}$, Roberto Argazzi ${ }^{\prime}$, Claudio Chiorboli', Angela Agostiano $^{\S, \neq}$, Massimo Trotta ${ }^{\ddagger, *}$ and Gianluca M. Farinola ${ }^{\S, *}$

† Istituto di Chimica dei Composti Organometallici, Consiglio Nazionale delle Ricerche - Bari, Italy

$\S$ Dipartimento di Chimica, Università degli Studi di Bari "Aldo Moro" - Bari, Italy

$\ddagger$ CNR-IPCF Istituto per i Processi Chimico Fisici, Consiglio Nazionale delle Ricerche - Bari, Italy

| Istituto di Sintesi Organica e Fotoreattività, Consiglio Nazionale delle Ricerche - Ferrara, Italy

Supplementary information 


\section{Solubility of $\mathrm{AE}_{800}$ in Triton $\mathrm{X} 100$ solutions}

Few $\mathrm{mg}$ of $\mathrm{AE}_{8 \mathrm{oo}}$ powder were kept under stirring for several hours in buffer solutions containing increasing amount of TXıo ranging from $0.3 \%$ to $3 \%$. In all cases, a portion of the initial powder is still present at the end of the experiment. From the Vis spectrum the dependence of $\mathrm{AE}_{800}$ solubility on TX concentration is obtained. Stock solution at $\mathrm{TX} 3 \%$ were used to convey the $\mathrm{AE}_{8 \mathrm{oo}}$ to the RC solution. Stock solutions were always freshly prepared and used within few hours.

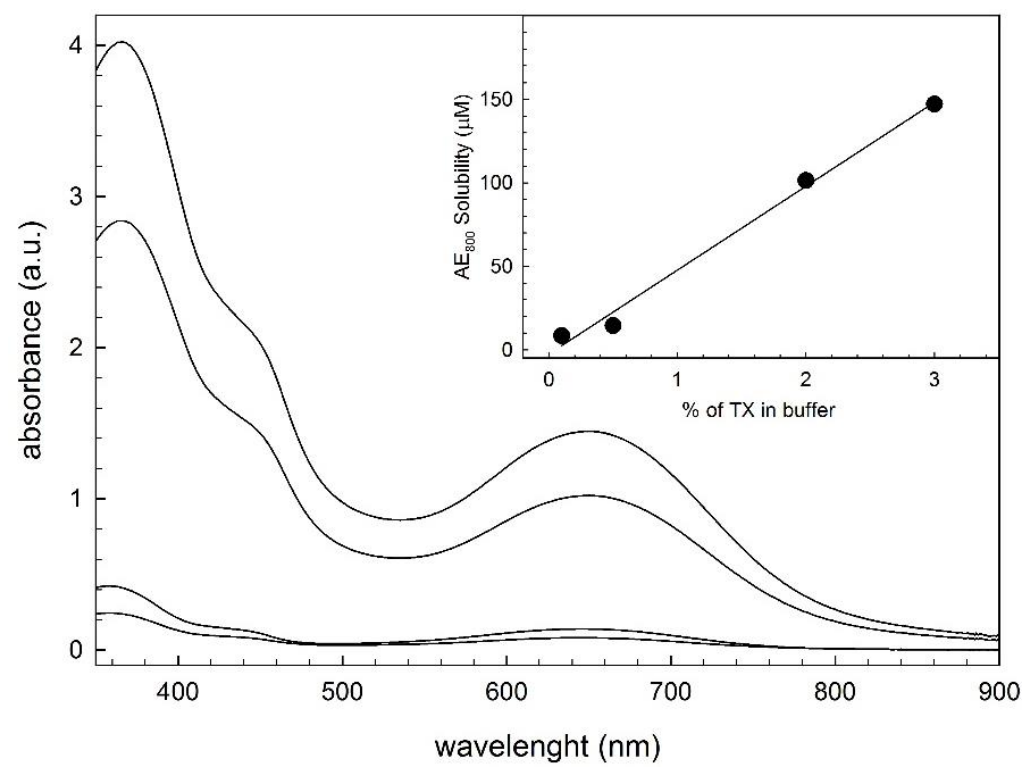

Figure S1. Absorption spectra of $\mathrm{AE}_{800}$ at different percentage of $\mathrm{TX}$ in $\mathrm{T}_{20} \mathrm{E}_{1}$ buffer at $\mathrm{pH}$ 8. Dependence of solubility on TX percentage in the buffer.

\section{Optical properties of core moiety (compound 9) and AE80o}

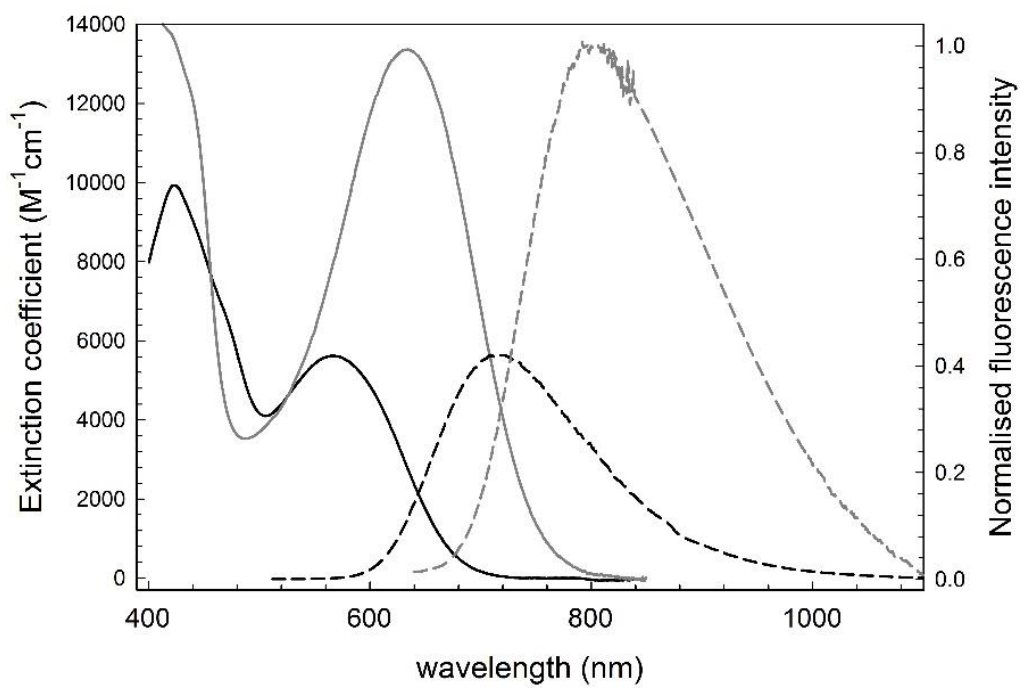

Figure S2. Absorption (full lines) and emission spectra (broken lines) of $\mathrm{AE}_{800}$ (gray) and core moiety (compound 9 in scheme 2) (black) in $\mathrm{CHCl}_{3}$. Fluorescence intensities are normalized to their relative absorbance spectra. 


\section{Charge recombination in pristine $\mathrm{RC}$ and in $\mathrm{RC}-\mathrm{AE}_{800}$ bioconjugate}

Charge recombination kinetics were recorded at $865 \mathrm{~nm}$ using a kinetic spectrophotometer of local design implemented with a Hamamatsu R928 photomultiplier and a white-saturating flash (duration less than 100 microseconds) used for saturating RC photoexcitation. The decay traces were recorded up to complete recovery (at least 4-5 longer than their decay times) and the samples were dark adapted for at least 5-6 times the time interval used for recording the signal. No drift induced by the measuring beam was found.Data were collected onto a Digital Oscilloscope (Tektronix TDS 3052 ).

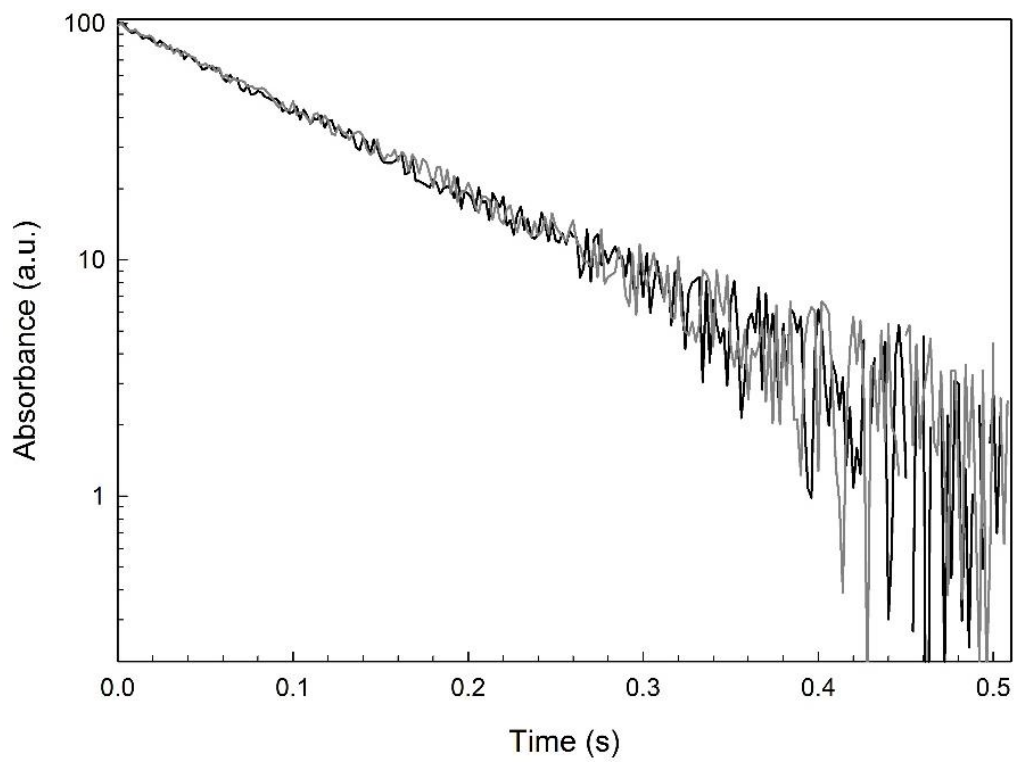

Figure S3. Time course of the charge-recombination reactions of the charge-separated states generated by a single flash of light in $\mathrm{RC}$ (gray), and $\mathrm{AE}_{800}-\mathrm{RC}$ (black). In both cases, the $\mathrm{Q}_{\mathrm{B}}$ functionality was inhibited by adding terbutryn $100 \mu \mathrm{M}$. RC 1 $\mu \mathrm{M}$, in $\mathrm{T}_{20} \mathrm{E}_{1} \mathrm{Tx}_{\mathrm{o.3}}, \mathrm{pH}$ 8.o. 


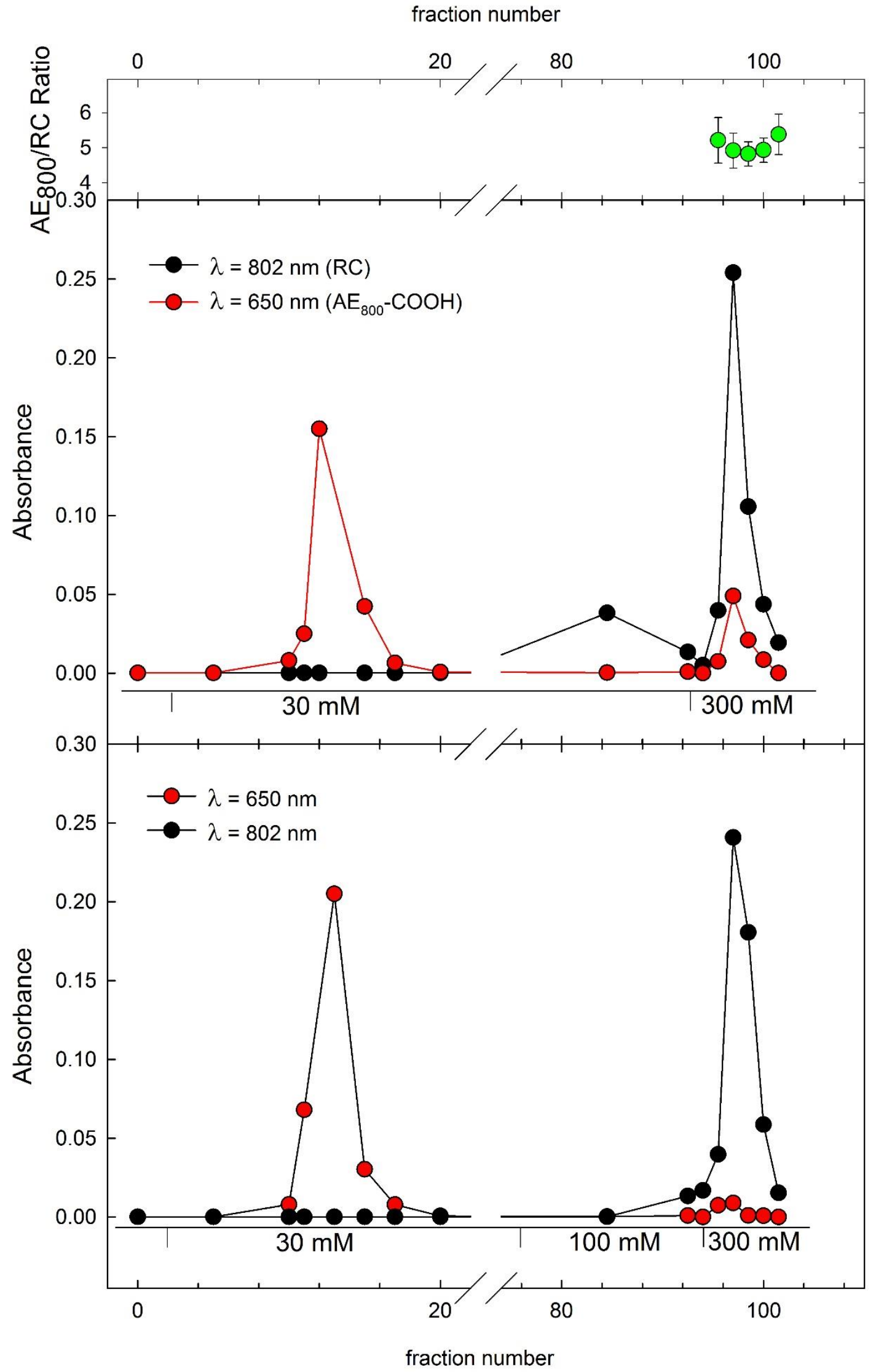

Figure $\mathrm{S}_{4}$. Ionic chromatography of $\mathrm{AE}_{800}-\mathrm{COOH}$ and $\mathrm{RC}$ (upper panel) after $1 \mathrm{~h}$ of incubation. No co-elution of the two components is visible. Ionic chromatography of $\mathrm{AE}_{800}-\mathrm{NHS}$ and $\mathrm{RC}$ (medium panel) after $1 \mathrm{~h}$ of incubation. Excess $\mathrm{AE}_{800^{-}}$ NHS elutes earlier than the bioconjugated $\mathrm{AE}_{800}-\mathrm{RC}$. A small fraction of unbound RC elutes at lower ionic strength. 


\section{Enhancement of RC photochemical activity}

Since RC remains undamaged and fully functional, with an increase of 2.4 times in the proton uptake during the photocycle rate we turned our attention to the increase of the amount of charge-separated state attainable in $\mathrm{AE}_{800}-\mathrm{RC}_{\text {as compared to }}$ the native protein. By irradiating at $800 \mathrm{~nm}$, where the spectral contribution of the artificial antenna is negligible, the sole $\mathrm{RC}$ pigments are directly excited and the amount of charge-separated state accumulated under illumination is equal in both $\mathrm{AE}_{800}-\mathrm{RC}$ and native RC. Having further demonstrated the ability of the protein to generate $\operatorname{CSS}$ (or $\mathrm{D}^{+} \mathrm{Q}_{\mathrm{A}}^{-}$) under continuous illumination at $800 \mathrm{~nm}$ used as reference wavelength, the enhancement of the $\mathrm{D}^{+} \mathrm{Q}_{\mathrm{A}}{ }^{-}$production in correspondence of $\mathrm{AE}_{800}$ absorption maxima was also measured by exciting the hybrid and the pristine protein at 450 and $650 \mathrm{~nm}$ respectively. $\mathrm{AE}_{800}-\mathrm{RC}$ outperforms $\mathrm{RC}$ by a factor of 5.1 and 2.7 at 450 and $650 \mathrm{~nm}$ respectively. The latter value is in good agreement with the increase of 2.4 times in the rate of the $\mathrm{AE}_{80 \mathrm{o}}-\mathrm{RC}$ photocycle measured by proton uptake at 650 $\mathrm{nm}$.

It is worth to note that all experiments are performed under subsaturating illumination conditions, i.e. having a $60 \%$ yield in the formation of $\mathrm{D}^{+} \mathrm{Q}_{\mathrm{A}}$ s state, to ensure the extent of photobleaching changes linearly with the light energy absorbed.

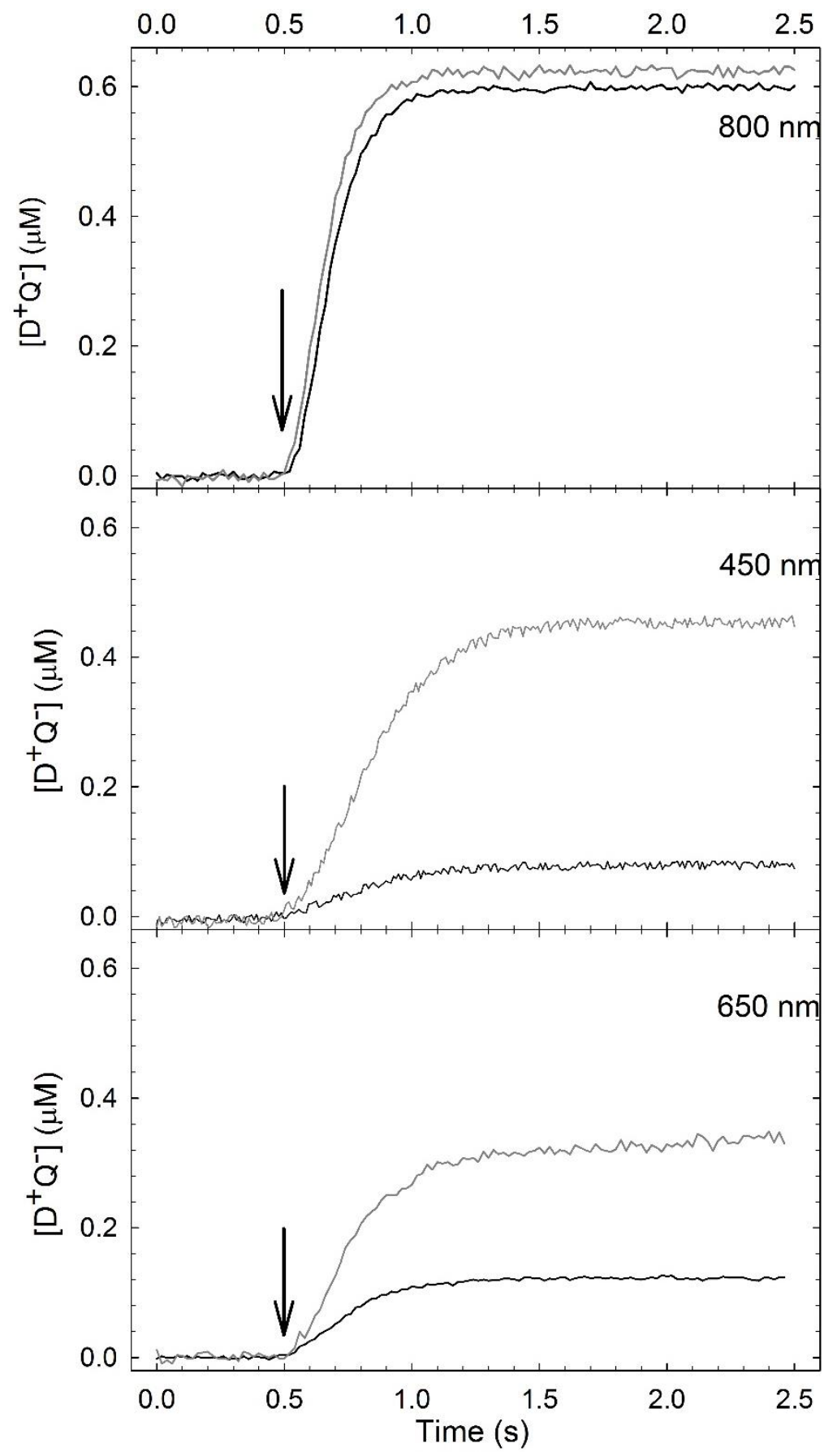


Figure $\mathrm{S}_{5}$. Concentration of $\mathrm{D}^{+} \mathrm{Q}_{\mathrm{A}}{ }^{-}$generated by continuous illumination at $800 \mathrm{~nm}, 450 \mathrm{~nm}$ and $650 \mathrm{~nm}$ for $\mathrm{AE} 8 \mathrm{Eo}^{-} \mathrm{RC}$ (gray) and RC (black). Measurements were carried out at the same photon flux at all wavelenghts. RC and AE-RC are $1 \mu \mathrm{M}$ in $\mathrm{T}_{20} \mathrm{E}_{1} \mathrm{TX}_{\mathrm{o} .03}$ buffer, $\mathrm{NaCl} 150 \mathrm{mM}$ in presence of $100 \mu \mathrm{M}$ terbutryn. $\mathrm{pH}$ 8.o. 


\section{Synthesis of $A E_{800}$}

All reactions were carried out under a nitrogen atmosphere in oven-dried glassware, with dry solvents, unless otherwise stated. Yields are average of two runs. THF and dichloromethane were distilled immediately prior to use from sodium/benzophenone and over phosphorus pentoxide, respectively. Diisopropylethylamine (DIPA) and DMSO were distilled over 4 Å molecular sieves and stored under nitrogen atmosphere. Anhydrous $N, N$-dimethylformamide, all starting materials and catalysts were purchased at the highest commercial purity degree from Sigma Aldrich and used without further purification. Compounds $\mathbf{2}^{1}, \mathbf{6}^{2,3,4}, \mathbf{8}^{5,6}$, and $\mathbf{1 0}^{7}$ were prepared in significantly improved yields with respect to published experimental protocols. Column chromatography was performed on flash silica gel 6o, (40-63 mm) from Merck, unless otherwise stated. Merck silica gel 6o F254 aluminum sheets were used for analytical TLC. All new compounds were characterized by FTIR, ${ }^{1} \mathrm{H}-\mathrm{NMR},{ }^{13} \mathrm{C}-\mathrm{NMR}$ spectroscopies and HMRS spectrometry. FTIR spectra were recorded using a Perkin-Elmer Spectrum BX spectrophotometer with dry $\mathrm{KBr}$ pellets. ${ }^{1} \mathrm{H}$ and ${ }^{13} \mathrm{C}$ NMR spectra were recorded at 500 and 125 $\mathrm{MHz}$ with a Bruker AM 500 spectrometer, using the residual peaks of $\mathrm{CDCl}_{3}$ at $7.26 \mathrm{ppm}$ and TMS at o.o ppm as the references for ${ }^{1} \mathrm{H}$ spectra and the signal of $\mathrm{CDCl}_{3}$ at $77.0 \mathrm{ppm}$ as standard for ${ }^{3} \mathrm{C}$ spectra. Coupling constants values $\mathrm{J}$ are given in Hz. High-resolution mass spectra were acquired on a Shimadzu high performance liquid chromatography-ion trap-time of flight mass spectrometer (LCMS-IT-TOF) via direct infusion of the samples using acetonitrile as the elution solvent. Melting points (uncorrected) were determined on a Reichert Microscope.

\section{Cross coupling reactions leading to $\mathrm{AE}_{800}$ (Scheme 1)}

\section{4-(7-((4-((2-ethylhexyl)oxy)phenyl)ethynyl)-2,3-dihydrothieno[3,4-b][1,4]dioxin-5-yl)-9-(7-iodo-2,3-dihydrothieno[3,4-} b][1,4]dioxin-5-yl)-6,7-di-p-tolyl-[1,2,5]thiadiazolo[3,4-g]quinoxaline (3):

An oven-dried Schlenk tube $50 \mathrm{~mL}$ equipped with magnetic stir bar and glass stopper was evacuated and backfilled with nitrogen ( 3 times). Then under a nitrogen flow it was charged with $\mathrm{Pd}\left(\mathrm{PPh}_{3}\right)_{2} \mathrm{Cl}_{2}$ (o.o12 g, o.o175 mmol, $5 \%$ vs 1), CuI (o.oo7 g, $0.0350 \mathrm{mmol}, 10 \% \mathrm{vs} \mathrm{1})$, diisopropylethylamine ( $5 \mathrm{~mL}, 1 / 3$ total vol of THF), carefully purified $\mathbf{1}(0.314 \mathrm{~g}, 0.349 \mathrm{mmol}) \mathrm{and}$ anhydrous THF (10 mL). The glass stopper was replaced with rubber septum and the mixture was stirred and degassed (through the septum by needle) with slight flow of nitrogen for 5 minutes, then a solution of 2 ( $0.084 \mathrm{~g}, 0.366 \mathrm{mmol}$ ) in anhydrous THF $(5 \mathrm{~mL})$ was added dropwise through the septum via syringe and the resulting mixture was stirred in the dark at room temperature for further $12 \mathrm{~h}$. TLC analysis showed the formation of a new product. The mixture was neutralized by addition of a saturated aqueous $\mathrm{NH}_{4} \mathrm{Cl}$ solution and extracted with dichloromethane (3x8o $\left.\mathrm{mL}\right)$. The organic extracts were collected, washed with water and dried over anhydrous $\mathrm{Na}_{2} \mathrm{SO}_{4}$, filtered and concentrated under reduced pressure. The crude product was purified by column chromatography on silica gel eluting with a mixture of hexane, dichloromethane and ethyl acetate in volumetric ratio 6:3:1. A dark green solid (0.172 g) was isolated in $49 \%$ yield. ${ }^{1} \mathrm{H}-\mathrm{NMR}$ $\left(500 \mathrm{MHz}, \mathrm{CDCl}_{3}\right) \delta$ 7.66-7.62 (m, $\left.4 \mathrm{H}\right), 7.50(\mathrm{~d}$ like, J $\approx 9.0 \mathrm{~Hz}, 2 \mathrm{H}), 7.15-7.18(\mathrm{~m}, 4 \mathrm{H}), 6.89$ (d like, J $\left.\approx 9.0 \mathrm{~Hz}, 2 \mathrm{H}\right), 4.49-4.42$ $(\mathrm{m}, 4 \mathrm{H}), 4.29-4.24(\mathrm{~m}, 4 \mathrm{H}), 3.89-3.86$ (two dd overlapped, J=11.o Hz, J=6.o Hz, $2 \mathrm{H}), 2.39(\mathrm{~s}, 6 \mathrm{H}), 1.71(\mathrm{septet}, \mathrm{J}=6.5 \mathrm{~Hz}, 1 \mathrm{H})$, 1.56-1.29 (m, 8H), 0.95 (two triplets overlapped, $J=7.5 \mathrm{~Hz}, 6 \mathrm{H}) \mathrm{ppm} .{ }^{13} \mathrm{C}-\mathrm{NMR}\left(125 \mathrm{MHz}, \mathrm{CDCl}_{3}\right): \delta=159.6,153.6,153.5,152.6$, 152.5, 144.2, 143.7, 140.4, 140.3, 140.00 (2 signals), 136.9, 136.6, 135.9, 135.8, 133.0, 130.1 (2 signals), 128.9, 120.9, 120.6, 115.9, 115.0, 114.5, 111.5, 103.0, 98.18, 78.8, 70.6, 65.2, 65.0, 64.6, 64.5, 54.6, 39.4, 30.5, 29.7, 29.10, 23.9, 23.0, 21.5, 14.10, 11.10 ppm. M.p.: 224 - $225^{\circ} \mathrm{C}$. FTIR: $v\left(\mathrm{~cm}^{-1}\right)=2959,2918,2850,1603,1489,1457,1356,1261,1245,1169,1074,807$. LCMS-IT-TOF calculated for $\mathrm{C}_{50} \mathrm{H}_{43} \mathrm{~N}_{4} \mathrm{O}_{5} \mathrm{~S}_{3} \mathrm{I} m / z=1003.1513[\mathrm{M}+\mathrm{H}]^{+}$. Found: $m / z=1003.1511$.

\section{4-(7-ethynyl-2,3-dihydrothieno[3,4-b][1,4]dioxin-5-yl)-9-(7-((4-(octyloxy)phenyl)ethynyl)-2,3-dihydrothieno[3,4- b] [1,4]dioxin-5-yl)-6,7-di-p-tolyl-[1,2,5]thiadiazolo[3,4-g]quinoxaline (4)}

The reaction and the work-up of the crude product were carried out according to the procedure reported for the synthesis of 3 and using the following amounts of reagents: 3 (o.20o g, o.199 mmol), anhydrous THF $(9 \mathrm{~mL}), \mathrm{PdCl}_{2}\left(\mathrm{PPh}_{3}\right)_{2}$ ( $0.0069 \mathrm{~g}$, $0.0099 \mathrm{mmol}, 5 \%$ vs 3), CuI (0.0038 g, $0.0199 \mathrm{mmol}, 10 \% \mathrm{vs} 3$ ), diisopropylethylamine (4.0 $\mathrm{mL}$ ) and a solution of trimethylsilylacetylene $(0.083 \mathrm{~mL}, 0.597 \mathrm{mmol})$ in anhydrous THF $(3 \mathrm{~mL})$. The crude product recovered from the previously described work-up was purified by column chromatography on silica gel eluting with a mixture of hexane, dichloromethane and ethyl acetate in volumetric ratio 6:3:1. The trimethylsilyl derivative obtained as a dark green solid ( $0.1750 \mathrm{~g}$, $0.1790 \mathrm{mmol}$ ) was dissolved in a mixture of methanol $(5 \mathrm{~mL})$ and acetone $(15 \mathrm{~mL})$ and directly subjected to the desilylation reaction with $\mathrm{KOH}$ powder $(0.0050 \mathrm{~g}$, $0.0895 \mathrm{mmol}, 0.5$ equivalent $v$ s the trimethylsilyl-derivative reagent). The solution was stirred at room temperature and, after $2 \mathrm{~h}$, TLC analysis showed the disappearance of the starting reagent. The mixture was then neutralized by addition of a saturated aqueous $\mathrm{NH}_{4} \mathrm{Cl}$ solution and extracted with dichloromethane $(3 \times 50 \mathrm{~mL})$. The organic extracts were collected and dried over anhydrous $\mathrm{Na}_{2} \mathrm{SO}_{4}$, filtered and concentrated under reduced pressure. The crude product was purified by column chromatography on silica gel using a mixture of hexane, dichloromethane, ethyl acetate $(6: 3: 1 \mathrm{vol})$ as the eluent. A dark green solid was isolated (o.1380 g, $77 \%$ overall yield). ${ }^{1} \mathrm{H}-$ NMR (500 MHz, $\left.\mathrm{CDCl}_{3}\right) \delta$ 7.66-7.61 $(\mathrm{m}, 4 \mathrm{H}), 7.50(\mathrm{~d}$ like, J $\approx 8.5 \mathrm{~Hz}, 2 \mathrm{H}), 7.19-7.13(\mathrm{~m}, 4 \mathrm{H}), 6.88(\mathrm{~d}$ like, J $\approx 8.5 \mathrm{~Hz}, 2 \mathrm{H})$, 4.49-4.44 (m, $4 \mathrm{H}), 4.30-4.25(\mathrm{~m}, 4 \mathrm{H}), 3.89-3.85$ (two dd overlapped, J= 11.0 Hz, J=6.o Hz, $2 \mathrm{H}), 3.67(\mathrm{~s}, 1 \mathrm{H}), 2.39(\mathrm{~s}, 6 \mathrm{H}), 1.71$ (septet, $\mathrm{J}=6.5 \mathrm{~Hz}, 1 \mathrm{H})$, 1.59-1.29 $(\mathrm{m}, 8 \mathrm{H})$, o.94 (two triplets overlapped, J = 7.5 Hz, 6H) ppm. ${ }^{13} \mathrm{C}-\mathrm{NMR}(125 \mathrm{MHz} \mathrm{CDCl}): \delta=$ $159.6,153.7,153.5,152.6,152.5,145.4,143.7,140.5,140.0,140.0,140.00,137.0,136.8,135.8$, 133.00, 130.1, 130.00, 129.8, 128.9, 121.16, 120.13 , 115.0o, 114.5, 112.16, 111.4, 103.16, 100.6, 98.2, 85.7, 78.8, 74.8, 70.6, 65.12, 65.0, 64.5, 64.4, 39.3, 30.5, 29.7, 29.10, 23.8, 23.0, 21.5, 14.13, 11.10 ppm. M.p.: 224-225 ${ }^{\circ}$ C. FTIR: $v\left(\mathrm{~cm}^{-1}\right)=3285,2921,2852,2360,2343,1604,1484,1461,1441,1359,1246,1076,822$. LCMS-IT-TOF calculated for $\mathrm{C}_{52} \mathrm{H}_{44} \mathrm{~N}_{4} \mathrm{O}_{5} \mathrm{~S}_{3} m / z=901.2547[\mathrm{M}+\mathrm{H}]^{+}$. Found: $m / z=901.2549$. 
2,5-dioxopyrrolidin-1-yl-4-(4-((7-(9-(7-((4-((2-ethylhexyl)oxy)phenyl)ethynyl)-2,3-dihydrothieno[3,4-b][1,4]dioxin-5yl)-6,7-di-p-tolyl-[1,2,5]thiadiazolo[3,4-g]quinoxalin-4-yl)-2,3-dihydrothieno[3,4-b][1,4]dioxin-5yl)ethynyl)phenyl)butanoate $\left(\mathrm{AE}_{800}\right)$

\section{For Troubleshooting relative to compound AE80o see below}

The reaction was carried out according to the procedure reported for the synthesis of 3 and using the following amounts of reagents: 5 (o.1030 g, 0.2670 mmol), anhydrous THF ( $3 \mathrm{~mL}$ ), $\mathrm{Pd}\left(\mathrm{PPh}_{3}\right)_{2} \mathrm{Cl}_{2}(0.0094 \mathrm{~g}$, $0.0134 \mathrm{mmol}, 5 \%$ vs 5 ), CuI (o.0051 g, $0.0267 \mathrm{mmol}, 10 \%$ vs 5), diisopropylethylamine $(2 \mathrm{~mL})$ and a solution of 4 ( $0.0800 \mathrm{~g}, 0.089 \mathrm{mmol})$ in anhydrous THF (3 $\mathrm{mL}$ ). After 12 hours, the reaction mixture was diluted with a saturated aqueous $\mathrm{NaCl}$ solution $(50 \mathrm{~mL})$ and ice, then extracted with dichloromethane $(3 \times 50 \mathrm{~mL})$. The combined organic extracts were dried over anhydrous $\mathrm{Na}_{2} \mathrm{SO}_{4}$, filtered and concentrated under reduced pressure. Vacuum distillation of the solvent was performed at temperature below $20^{\circ} \mathrm{C}$ to avoid product decomposition. The crude product was purified by column chromatography on silica gel eluting with dichloromethane and methanol in volumetric ratio 95:5. A dark green solid $(\mathrm{o.082} \mathrm{g})$ was isolated in $80 \%$ yield.. ${ }^{1} \mathrm{H}-\mathrm{NMR}$ $\left(500 \mathrm{MHz}, \mathrm{CDCl}_{3}\right) 7.65$ (d like, J $\left.\approx 8.0 \mathrm{~Hz}, 4 \mathrm{H}\right), 7.54-7.47(\mathrm{~m}, 4 \mathrm{H}), 7.20(\mathrm{~d}$ like, J $\approx 8.0 \mathrm{~Hz}, 2 \mathrm{H}), 7.16(\mathrm{~d}$ like, J $\approx 8.0 \mathrm{~Hz}, 4 \mathrm{H})$, 6.88 (d like, J $\approx 8.0 \mathrm{~Hz}, 2 \mathrm{H}), 6.88(\mathrm{~d}, \mathrm{~J} \approx 8.5 \mathrm{~Hz}, 2 \mathrm{H}), 4.5 \mathrm{O}-4.44(\mathrm{~m}, 4 \mathrm{H}), 4.30-4.24(\mathrm{~m}, 4 \mathrm{H}), 3.90-3.84$ (two dd overlapped, J= $11.0 \mathrm{~Hz}, \mathrm{~J}=6.0 \mathrm{~Hz}, 2 \mathrm{H}), 2.85$ (broad s, $4 \mathrm{H}), 2.76(\mathrm{t}, \mathrm{J}=7.5 \mathrm{~Hz}, 2 \mathrm{H}), 2.627(\mathrm{t}, \mathrm{J}=7.5 \mathrm{~Hz}, 2 \mathrm{H}), 2.39(\mathrm{~s}, 6 \mathrm{H}), 2.087$ (quintuplet, J = $7.5 \mathrm{~Hz}, 2 \mathrm{H}), 1.71$ (septet, J = 6.5 Hz, 1H), 1.56-1.30 (m, 8H), 0.94 (two triplets overlapped, J = 7.5 Hz, 6H) ppm. ${ }^{13} \mathrm{C} \mathrm{NMR}(125$ $\left.\mathrm{MHz}, \mathrm{CDCl}_{3}\right) \delta 169.10,168.3,159.6,153.5,153.4,152.6,144.0,143.7,141.10$, 140.4, 140.4, 140.0 (two signals), 136.9 (two signals), 135.9, 133.0, 131.7, 130.12, 128.9, 128.5, 121.17, 120.8, 120.6, 115.0, 114.5, 111.9, 111.5, 103.0, 102.5, 98.16, 97.9, 80.13, 78.9, 70.6, 65.0, 64.5, 39.3, 34.5, 31.9, 30.5, 30.16, 29.7, 29.10, 26.0, 25.6, 23.8, 23.0, 22.7, 21.4, 14.0, 11.1 ppm. M.p.: 88-90 ${ }^{\circ} \mathrm{C}$. FTIR: $v\left(\mathrm{~cm}^{-1}\right)=$ 2959, 2919, 2850, 2193, 1740, 1604, 1482, 1441, 1358, 1260, 1073, 1021, 801. LCMS-IT-TOF calculated for $\mathrm{C}_{66} \mathrm{H}_{57} \mathrm{~N}_{5} \mathrm{O}_{9} \mathrm{~S}_{3}$ $m / z=1160.3391[\mathrm{M}]^{+}$. Found: $m / z=1160.3378$.

\section{Troubleshooting relative to compound AE80o}

2,5-dioxopyrrolidin-1-yl-4-(4-((7-(9-(7-((4-((2-ethylhexyl)oxy)phenyl)ethynyl)-2,3-dihydrothieno[3,4-b][1,4]dioxin5-yl)-6,7-di-p-tolyl-[1,2,5] thiadiazolo[3,4-g]quinoxalin-4-yl)-2,3-dihydrothieno[3,4-b][1,4]dioxin-5yl)ethynyl)phenyl)butanoate $\left(\mathrm{AE}_{800}\right)$

After the reaction and the work-up of the crude product, sometimes we observed via TLC a mixture of Nhydroxysuccinimidyl ester and the caboxylic acid derivative and we proceeded as follows: the mixture was passed through a gravimetric and/or flash silica gel column chromatography, eluting with a mixture of hexane, dichloromethane and ethyl acetate in volumetric ratio 3:4:3, we found that the combination of the gravimetric and / or flash silica gel and our eluent (3:4:3) promoted the hydrolysis of the NHS ester to the free acid derivative in the column, also during the chromatography we did not observe in the fractions the presence of NHS ester and/or to the acid. To achieve the pure carboxylic acid derivative from the column, it was eluted with the mixture (95:5, dichloromethane:methanol), to obtain it as a dark green solid $0.0850 \mathrm{~g}$ in $90 \%$ yield. Then the caboxylic acid derivative (0.085og, $0.0800 \mathrm{mmol}$ ) was transferred in an oven-dried $50 \mathrm{~mL}$ three necked round bottom flask. The system was purged with nitrogen. Then $10 \mathrm{ml}$ of a dry dichloromethane and $\mathrm{N}-$ hydroxysuccinimide $(0.0138 \mathrm{~g}, 0.120 \mathrm{mmol})$ was introduced, followed by cooling the system at $0^{\circ} \mathrm{C}$, finally $1^{-}$-ethyl-3-(3dimethylaminopropyl)carbodiimide $(0.0230 \mathrm{~g}, 0.120 \mathrm{mmol})$ was charged, after stirring for 30 minutes at $0^{\circ} \mathrm{C}$ the mixture was allowed to reach room temperature. After $3 \mathrm{~h}$ TLC analysis confirmed the formation of AE8oo. $\mathrm{NaCl}$ solution (50 $\mathrm{mL}$ ) and ice was added and the crude product was extracted with dichloromethane $(3 \times 50 \mathrm{~mL})$. The organic extracts were collected and dried over $\mathrm{Na}_{2} \mathrm{SO}_{4}$, filtered and concentrated under reduced pressure. The crude product was purified by column chromatography on flash silica gel eluting with dichloromethane and methanol in volumetric ratio 95:5. A dark green solid AE80o (0.0725 g) was isolated in $78 \%$ yield. During vacuum distillation of the solvent at the rotary evaporator, the temperature of the water bath was kept below $20^{\circ} \mathrm{C}$.

\section{Reactions leading to the building block (1) (Scheme 2)}

\section{4,7-dibromo-5,6-dinitrobenzo[c][1,2,5]thiadiazole (6)}

A $100 \mathrm{~mL}$ round bottom flask equipped with a dropping funnel and magnetic stir bar was charged with $15 \mathrm{~mL}$ of fuming trifluoromethane sulphonic acid. Temperature was kept below $4^{\circ} \mathrm{C}$ and 4,7-dibromobenzo[c][1,2,5]thiadiazole (1.00o g, 3.40 $\mathrm{mmol}$ ) was added in small portions over a period of 30 minutes. Fuming nitric acid $(15 \mathrm{~mL})$ was finally added dropwise. The reaction was allowed to warm to room temperature and stirred overnight. Then, TLC analysis revealed the disappearance of the starting material. The reaction mixture was poured slowly in a beaker containing ice/water and the solid precipitate was recovered by filtration, washed with water several times and dried under reduced pressure. The crude material was purified by column chromatography on silica gel, eluting with a mixture of hexane:dichloromethane:diethyl ether in volumetric ratio 60:36:4. A yellow solid $(1.163 \mathrm{~g})$ was isolated in $89 \%$ yield. ${ }^{13} \mathrm{C}-\mathrm{NMR}\left(125 \mathrm{MHz}, \mathrm{CDCl}_{3}\right): \delta 151.4,144.9,110.3$ ppm. M.p.: $198-199^{\circ} \mathrm{C}$ (Lit. M. p.: $\left.201^{\circ} \mathrm{C}\right) .^{2}$ 


\section{Preparation of compound 6 with the classical pair $\mathrm{H}_{2} \mathrm{SO}_{4} / \mathrm{HNO}_{3}$}

Our preparative procedure of compound 6, also when the classical pair $\mathrm{H}_{2} \mathrm{SO}_{4} / \mathrm{HNO}_{3}$ for the nitration is used, led to better yield $(40 \%)$ than those using the same pair in the literature ${ }^{2,3}(27-29 \%)$.

\section{4,7-dibromo-5,6-dinitrobenzo[c][1,2,5] thiadiazole (6)}

The reaction and the work-up of the crude product were carried out according to the procedure reported for the synthesis of 6 , using the following amounts of reagents $15 \mathrm{ml}$ of fuming $\mathrm{H}_{2} \mathrm{SO}_{4}, 4,7$-dibromobenzo[c] $[1,2,5]$ thiadiazole (1.oo g, $3.40 \mathrm{mmol}$ ) and $15 \mathrm{ml}$ of Fuming nitric acid. The crude material was purified by column chromatography on silica gel, eluting with a mixture of hexane: dichloromethane: diethyl ether in volumetric ratio 60:36:4. A yellow solid (o.524 g) was isolated in $40 \%$ yield.

\section{4,9-dibromo-6,7-di-p-tolyl-[1,2,5]thiadiazolo[3,4-g]quinoxaline (7)}

An oven-dried $250 \mathrm{~mL}$ three necked round bottom flask equipped with a magnetic stir bar and water condenser was purged with nitrogen and charged with Fe powder (3.80 g, $68.04 \mathrm{mmol})$. Under a nitrogen flow, the system was heated with a heat-gun for $10 \mathrm{~min}$ to dry it and then cooled to room temperature. Then $120 \mathrm{~mL}$ of acetic acid, previously degassed by a nitrogen flow, were added. Finally, $6(2.18 \mathrm{~g}, 5.7 \mathrm{mmol})$ was introduced. The mixture was degassed for further $10 \mathrm{~min}$ and heated at $100{ }^{\circ} \mathrm{C}$ for $3 \mathrm{~h}$ under stirring. The complete disappearance of the starting product was confirmed by TLC. The mixture was allowed to cool to room temperature and poured in a beaker containing an ice cooled $5 \%$ solution of $\mathrm{NaOH}$ $(200 \mathrm{~mL})$. The precipitate was recovered via filtration, washed with water several times and dried. The residue was dissolved in hot EtOAc $(2 \times 200 \mathrm{~mL})$ and filtered to remove unreacted iron. The collected solution was distilled under reduced pressure, isolating $1.66 \mathrm{~g}$ of diamine product as a yellow solid in $90 \%$ yield. The diamine product (1.300 g, 4.o1mmol) was transferred in an oven-dried $250 \mathrm{~mL}$ three necked round bottom flask. The system was purged with nitrogen and acetic acid (100 mL), previously degassed by a nitrogen flow, was added. Finally 1,2-di-p-tolylethane-1,2-dione (1.150 g, $4.81 \mathrm{mmol}$ ) was introduced. The mixture was degassed for further $10 \mathrm{~min}$ and heated at $100^{\circ} \mathrm{C}$ for 12 hours. After cooling to room temperature, the mixture was poured into water and extracted with dichloromethane $(3 \mathrm{x} 100 \mathrm{~mL})$. The collected organic extracts were washed with a saturated $\mathrm{NaCl}$ aqueous solution and dried over anhydrous sodium sulfate. The solvent was distilled at reduced pressure. Since the product and the unreacted diketone have the same $R_{f}$ in chromatography, the crude material was treated with boiling methanol to remove the unreacted diketone, the solid was filtered off, dried under vacuum and purified by short column chromatography on silica gel, eluting with a mixture of hexane:dichloromethane in volumetric ratio $4: 6$. An orange solid $(1.94 \mathrm{~g})$ was obtained in $92 \%$ yield. ${ }^{1} \mathrm{H}-\mathrm{NMR}(500 \mathrm{MHz}$, $\left.\mathrm{CDCl}_{3}\right) \delta_{7.66}(\mathrm{~d}, \mathrm{~J} \approx 8.0 \mathrm{~Hz}, 4 \mathrm{H}), 7.21(\mathrm{~d}, \mathrm{~J} \approx 8.0 \mathrm{~Hz}, 4 \mathrm{H}), 2.41(\mathrm{~s}, 6 \mathrm{H}) \mathrm{ppm} .{ }^{13} \mathrm{C}-\mathrm{NMR}\left(125 \mathrm{MHz}, \mathrm{CDCl}_{3}\right): \delta=156.0,152.2,140.9$, 138.1, 134.9, 130.2, 129.14, 113.8, 21.5 ppm. M.p.: decomposition at $235^{\circ} \mathrm{C}$. FTIR: $v\left(\mathrm{~cm}^{-1}\right)=3028,2916,1606,1361,1263,1249,1190$, 987, 856, 818. LCMS-IT-TOF calculated for $\mathrm{C}_{22} \mathrm{H}_{14} \mathrm{~N}_{4} \mathrm{SBr}_{2} \mathrm{~m} / \mathrm{z}=524.9379[\mathrm{M}+\mathrm{H}]^{+}$. Found: $\mathrm{m} / \mathrm{z}=524.9367$.

\section{2-(2,3-dihydrothieno[3,4-b][1,4]dioxin-5-yl)-4,4,5,5-tetramethyl-1,3,2-dioxaborolane (8)}

In an oven-dried $100 \mathrm{~mL}$ three-necked round bottom flask equipped with a magnetic stir bar and rubber septa, a solution of 3,4-ethylenedioxythiophene (3.00 g, $21.10 \mathrm{mmol})$ in dry THF $(35 \mathrm{~mL})$ was introduced under a nitrogen flow. After cooling to $-78{ }^{\circ} \mathrm{C}$, a solution of $n$-Buli $2.5 \mathrm{M}$ in hexane $(9.30 \mathrm{~mL}, 23.12 \mathrm{mmol})$ was added dropwise through the septum via syringe. Then, the temperature was slowly raised to $0{ }^{\circ} \mathrm{C}$ and the mixture was stirred for $30 \mathrm{~min}$. After cooling again the temperature at $-78{ }^{\circ} \mathrm{C}$, a solution of 2-isopropoxy-4,4,5,5'-tetramethyl-1,3,2-dioxaborolane (8.6o $\mathrm{mL}, 42.20 \mathrm{mmol}$ ) in dry THF $(5 \mathrm{~mL})$ was added through the septum via syringe under a nitrogen atmosphere. The reaction mixture was then allowed to reach room temperature and the mixture was stirred for further $12 \mathrm{~h}$. The formation of the expected product was verified by TLC. After quenching with ice and $\mathrm{NaCl}$ saturated aqueous solution, the mixture was extracted with $\mathrm{Et}_{2} \mathrm{O}$ (3xioo $\mathrm{mL}$ ). The collected organic extracts were washed with water and dried over anhydrous $\mathrm{Na}_{2} \mathrm{SO}_{4}$, and the solvent was evaporated at reduced pressure. The crude material was purified as a white solid ( $5.375 \mathrm{~g}, 95 \%$ yield) by crystallization from hexane. ${ }^{1} \mathrm{H}-\mathrm{NMR}\left(500 \mathrm{MHz}, \mathrm{CDCl}_{3}\right) \delta 6.62(\mathrm{~s}, 1 \mathrm{H}), 4 \cdot 31-4.27(\mathrm{~m}, 2 \mathrm{H})$, 4.19-4.15 (m, 2H) 1.33 (s, 12H) ppm. M.p.: 79-80 ${ }^{\circ} \mathrm{C}$. (Lit. M. p.: $\left.87-88^{\circ} \mathrm{C}\right){ }^{6}$

\section{4,9-bis(2,3-dihydrothieno[3,4-b][1,4]dioxin-5-yl)-6,7-di-p-tolyl-[1,2,5]thiadiazolo[3,4-g]quinoxaline (9)}

An oven-dried Schlenk tube equipped with a water condenser and magnetic stir bar was evacuated and backfilled with nitrogen (3 times). Then, it was charged under a nitrogen flow with 7 (o.35o g, o.66 mmol), 8 (o.535 g, 1.99 mmol), $\mathrm{Pd}(\mathrm{OAc})_{2}$ (o.008 g, $0.033 \mathrm{mmol}$ ), 2-dicyclohexylphosphino-2',6'-dimethoxybiphenyl (o.027 g, o.066 mmol), powdered anhydrous $\mathrm{K}_{3} \mathrm{PO}_{4}(0.423 \mathrm{~g}, 1.99 \mathrm{mmol})$ and dry tetrahydrofuran $(12 \mathrm{~mL})$. Previously degassed and distilled water (1.2 $\left.\mathrm{mL}\right)$ was finally added and the mixture was heated to $85^{\circ} \mathrm{C}$ overnight. The complete disappearance of the dihalide 7 was then observed by TLC analysis. The reaction mixture was cooled to room temperature, filtered through a thin pad of silica gel (eluting with dichloromethane: ethyl acetate in volumetric ratio 1:1) and concentrated under reduced pressure. The crude product was purified by column chromatography on silica gel, using a mixture of hexane, diethyl ether and ethyl acetate $(5: 3: 2 \mathrm{vol})$ as the eluent. A dark purple solid was isolated $(0.423 \mathrm{~g})$ in $98 \%$ yield. ${ }^{1} \mathrm{H}-\mathrm{NMR}\left(500 \mathrm{MHz}, \mathrm{CDCl}_{3}\right) \delta 7.66-7.61(\mathrm{~d}$ like, J $\approx 8.5,4 \mathrm{H}), 7.17-7.12(\mathrm{~d}$ like, $\mathrm{J} \approx 8.5,4 \mathrm{H}), 6.76(\mathrm{~s}, 2 \mathrm{H}), 4.4 \mathrm{o}-4.34(\mathrm{~m}, 4 \mathrm{H}), 4.30-4.24(\mathrm{~m}, 4 \mathrm{H}), 2.38(\mathrm{~s}, 6 \mathrm{H}) \mathrm{ppm} .{ }^{13} \mathrm{C}-$ NMR (125 MHz, $\left.\mathrm{CDCl}_{3}\right): \delta=153.3,152.7,141.5,141.1,139.8,136.7,136.0,130.13,128.8,121.3,110.5,103.3,64.7,64.6,21.4$ ppm. M. p.: decomposition at $245^{\circ} \mathrm{C}$. FTIR: $v\left(\mathrm{~cm}^{-1}\right)=2915,2867,1605,1488,1446,1362,1165,1069$, 904. LCMS-IT-TOF calculated for $\mathrm{C}_{34} \mathrm{H}_{24} \mathrm{~N}_{4} \mathrm{O}_{4} \mathrm{~S}_{3} m / z=649.1032[\mathrm{M}+\mathrm{H}]^{+}$. Found: $m / z=649.1009$. 


\section{4,9-bis(7-iodo-2,3-dihydrothieno[3,4-b][1,4]dioxin-5-yl)-6,7-di-p-tolyl-[1,2,5]thiadiazolo[3,4-g]quinoxaline (1)}

A $100 \mathrm{~mL}$ three-necked round bottom flask equipped with a stir bar and rubber septum was charged under a nitrogen flow with 9 ( $0.242 \mathrm{~g}, 0.373 \mathrm{mmol}$ ) and dry $N, N$-dimethylformamide (10 mL). The mixture was cooled to $-20{ }^{\circ} \mathrm{C}$ and $N$ iodosuccinimide (o.170 g, $0.573 \mathrm{mmol}$ ), previously dissolved in $4 \mathrm{~mL}$ of dry DMF, was added dropwise through the septum via syringe. The system was protected from light with aluminum foil and kept at $-20^{\circ} \mathrm{C}$ for 2 hours. Then it was allowed to warm to room temperature. The complete disappearance of the reagent was observed by TLC. A saturated aqueous solution of $\mathrm{NH}_{4} \mathrm{Cl}$ was added and the mixture was extracted with ethyl acetate $(3 \times 6 \mathrm{omL})$. The organic extracts were collected and washed with a saturated aqueous solution of $\mathrm{NaCl}(3 \times 150 \mathrm{~mL})$, dried over $\mathrm{Na}_{2} \mathrm{SO}_{4}$, filtered and concentrated under reduced pressure. The crude product was purified by column chromatography on silica gel eluting with hexane, dichloromethane and ethyl acetate in volumetric ratio 6:3.1. A dark green powder was isolated (o.319 g, 95\% yield). ${ }^{1} \mathrm{H}-\mathrm{NMR}$ $\left(500 \mathrm{MHz}, \mathrm{CDCl}_{3}\right) \delta 7.63(\mathrm{~d}$ like, J $\approx 8.0 \mathrm{~Hz}, 4 \mathrm{H}), 7.15$ (d like, J $\left.\approx 8.0 \mathrm{~Hz}, 4 \mathrm{H}\right), 6.76(\mathrm{~s}, 2 \mathrm{H}), 4.38-4.34(\mathrm{~m}, 4 \mathrm{H}), 4.29-4.25(\mathrm{~m}$, $4 \mathrm{H}) 2.38(\mathrm{~s}, 6 \mathrm{H}) \mathrm{ppm} .{ }^{13} \mathrm{C}-\mathrm{NMR}\left(125 \mathrm{MHz}_{\mathrm{CDCl}}\right): \delta=153.6,152.4,144.2,140.3,140.0,136.6,135.8,130.1,128.9,120.8,115.8$, 65.19, 64.6, 54.7, 21.4 ppm. M.p.> 270 ${ }^{\circ} \mathrm{C}$ (not found). FTIR: $v\left(\mathrm{~cm}^{-1}\right)=2978,2918,2868,1607,1493,1424,1353,1090,1073,902$. LCMS-IT-TOF calculated for $\mathrm{C}_{34} \mathrm{H}_{22} \mathrm{~N}_{4} \mathrm{O}_{4} \mathrm{~S}_{3} \mathrm{I}_{2} m / z=900.8965[\mathrm{M}+\mathrm{H}]^{+}$. Found: $m / z=900.8952$.

\section{Reactions leading to the ethynyl derivative (2) and the aryl halide (5) (Schemes 3 and 4 )}

1-((2-ethylhexyl)oxy)-4-iodobenzene (10) A $250 \mathrm{~mL}$ three-necked round bottom flask equipped with a magnetic stir bar was charged with $\mathrm{KOH}$ powder $(6.890 \mathrm{~g}, 122.7 \mathrm{mmol})$ and DMSO $(70 \mathrm{~mL})$. The mixture was stirred until complete dissolution of $\mathrm{KOH}$; then 4 -iodohydroxybenzene $(6.000 \mathrm{~g}, 27.3 \mathrm{mmol})$ was added. The mixture was stirred for further 30 min and 2-ethylhexyl bromide $(9.70 \mathrm{~mL}, 54.5 \mathrm{mmol}$ ) was added dropwise. After further 12 hours at room temperature, TLC analysis showed the disappearance of the starting material and saturated aqueous solution of $\mathrm{NaCl}$ (10o $\mathrm{mL}$ ) was added to the mixture. The crude product was extracted with hexane $(3 \times 100 \mathrm{LL})$ and the combined organic phases were washed with $\mathrm{NaOH}$ aq $10 \%(2 \times 100 \mathrm{~mL})$ and water $(2 \times 100 \mathrm{~mL})$. After drying with anhydrous $\mathrm{Na}_{2} \mathrm{SO}_{4}$, the solvent was evaporated under reduced pressure and the crude product purified by column chromatography on silica gel using hexane as the eluent. A colorless oil (8.90 g) was isolated in $98 \%$ yield. ${ }^{1} \mathrm{H}-\mathrm{NMR}\left(500 \mathrm{MHz}, \mathrm{CDCl}_{3}\right) \delta$ 7.56-7.52 (d like, J $\left.\approx 9.0 \mathrm{~Hz}, 2 \mathrm{H}\right), 6.70-6.65(\mathrm{~d}$ like, J $\approx 9.0 \mathrm{~Hz}, 2 \mathrm{H}$ ), 3.83- 3.76 (two dd overlapped, J= 11.o Hz, J=6.o Hz, 2H), 1.71 (septet, J = 6.5 Hz, $1 \mathrm{H}), 1.53-1.24(\mathrm{~m}, 8 \mathrm{H})$, 0.94-0.86 (two multiplets overlapped, $6 \mathrm{H}$ ) ppm. ${ }^{13} \mathrm{C}-\mathrm{NMR}\left(125 \mathrm{MHz}, \mathrm{CDCl}_{3}\right) \delta=159.59,133.39,114.90,114.36,105.36,92.20$, 70.56, 39.31, 30.48, 29.06, 23.82, 23.01, 14.05, $11.08 \mathrm{ppm}^{7}$

\section{1-((2-ethylhexyl)oxy)-4-ethynylbenzene (2)}

The reaction and the work-up of the crude product were carried out according to the procedure reported for the synthesis of 3 and using the following amounts of reagents: 10 (o.80o g, 2.410 mmol) in anhydrous THF (6 mL), $\mathrm{PdCl}_{2}\left(\mathrm{PPh}_{3}\right)_{2}$ (0.034 g, $0.048 \mathrm{mmol}, 2 \%$ vs 10), CuI (0.018 g, $0.096 \mathrm{mmol}, 2 \%$ vs 10), diisopropylethylamine (2.0 $\left.\mathrm{mL}\right)$ and a solution of trimethylsilylacetylene $(0.670 \mathrm{~mL}, 4.82 \mathrm{mmol})$ in anhydrous THF $(2 \mathrm{~mL})$. The crude product recovered from the previously described work-up was purified by column chromatography on silica gel eluting with a mixture of hexane:dichloromethane in volumetric ratio 95:5. The trimethylsilyl derivative obtained as a colorless oil (o.672 g, 2.220 mmol) was dissolved in a mixture of methanol $(10 \mathrm{~mL})$ and acetone $(30 \mathrm{~mL})$ and directly subjected to the desilylation reaction with $\mathrm{KOH}$ ( $0.062 \mathrm{~g}$, $1.11 \mathrm{mmol}$, 0.5 equiv vs the trimethylsilyl-derivative reagent). The solution was stirred at room temperature and TLC analysis performed after two hours showed the disappearance of the starting reagent. The mixture was then neutralized by addition of saturated aqueous $\mathrm{NH}_{4} \mathrm{Cl}$ solution $(50 \mathrm{~mL})$ and extracted with hexane $(3 \times 6 \mathrm{omL})$. The organic extracts were collected and dried over anhydrous $\mathrm{Na}_{2} \mathrm{SO}_{4}$, filtered and concentrated under reduced pressure. The crude product was purified by column chromatography on silica gel using hexane as the eluent. A colorless oil was isolated to obtain $0.463 \mathrm{~g}$, in $91 \%$ yield (for the desilylation reaction) and/or in $83 \%$ (overall yield, starting from the aryl iodide 10 ). ${ }^{1} \mathrm{H}-\mathrm{NMR}\left(500 \mathrm{MHz}, \mathrm{CDCl}_{3}\right.$ ) $\delta 7.45-7.362$ (d like, J $\left.\approx 8.5 \mathrm{~Hz}, 2 \mathrm{H}\right), 6.88-6.815$ (d like, J $\approx 8.5 \mathrm{~Hz}, 2 \mathrm{H}$ ), 3.86- 3.80 (two dd overlapped, J= 11.0 Hz, J=6.o Hz, $2 \mathrm{H}$ ), $2.99(\mathrm{~s}, 1 \mathrm{H})$, 1.72 (septet, J = 6.o Hz, 1H), 1.53-1.24 (m, 8H), o.96-o.85 (two multiplets overlapped, 6H) ppm. ${ }^{13} \mathrm{C}-\mathrm{NMR}\left(125 \mathrm{MHz}, \mathrm{CDCl}_{3}\right) \delta=159.6,133.4,114.9,114.4,105.4,92.2,70.6,39.3,30.5,29.10,23.8,23.0$, 14.10, $11.10 \mathrm{ppm}$.

\section{2,5-dioxopyrrolidin-1-yl-4-(4-iodophenyl)butanoate (5)}

A $100 \mathrm{~mL}$ three necked round bottom flask equipped with a magnetic stir bar was conditioned with nitrogen flow and charged with 4-(4-iodophenyl)butanoic acid (2.00o g, $6.89 \mathrm{mmol})$, dry dichloromethane (40 $\mathrm{mL}), \mathrm{N}$-hydroxysuccinimide ( $0.952 \mathrm{~g}, 8.27 \mathrm{mmol})$ and cooled at $\mathrm{o}^{\circ} \mathrm{C}$. 1-Ethyl-3-(3-dimethylaminopropyl) carbodiimide (1.585 g, $8.27 \mathrm{mmol}$ ) was added and. after $30 \mathrm{~min}$, the mixture was allowed to reach room temperature. After $3 \mathrm{~h}$ TLC analysis confirmed the formation of $\mathbf{5}$. Water was added and the crude product was extracted with dichloromethane $(3 \mathrm{x} 8 \mathrm{o} \mathrm{mL})$. The organic extracts were collected and dried over $\mathrm{Na}_{2} \mathrm{SO}_{4}$, filtered and concentrated under reduced pressure. The crude product was purified by column chromatography on silica gel eluting with the solvent mixture hexane/dichloromethane/ethyl acetate in volume ratio 40:40:20. A white solid was isolated $(2.490 \mathrm{~g})$ in $93 \%$ yield. ${ }^{1} \mathrm{H}-\mathrm{NMR}\left(500 \mathrm{MHz}, \mathrm{CDCl}_{3}\right) \delta 7.63-7.59$ (d like, J $\approx 9.0$, $2 \mathrm{H}), 6.98-6.93(\mathrm{~d}$ like, J $\approx 9.0,2 \mathrm{H}), 2.91-2.77(\mathrm{~m}, 4 \mathrm{H}), 2.71-2.65(\mathrm{~m}, 2 \mathrm{H}), 2.59(\mathrm{t}, \mathrm{J}=7.3,2 \mathrm{H}), 2.09-1.99(\mathrm{~m}, 2 \mathrm{H}) . \mathrm{ppm} .{ }^{13} \mathrm{C}-$ NMR $\left(125 \mathrm{MHz}_{\mathrm{CDCl}}\right): \delta=169.1,168.3,140.2,137.6,130.6,91.3$, 34.00, 30.1, 26.00, 25.6 ppm. M.p.: $78-79^{\circ} \mathrm{C}$. FTIR: $v\left(\mathrm{~cm}^{-1}\right)=$ 2949, 1800, 1775, 1731, 1218, 1115, 1070, 810. LCMS-IT-TOF calculated for $\mathrm{C}_{14} \mathrm{H}_{14} \mathrm{NO}_{4} \mathrm{I} \mathrm{m} / \mathrm{z}=409.9860[\mathrm{M}+\mathrm{Na}]^{+} \mathrm{Found}$ $\mathrm{m} / \mathrm{z}=409.9833$. 


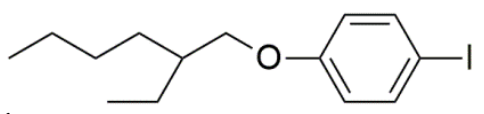

${ }^{1} \mathrm{H}$-NMR Spectrum of compound 10
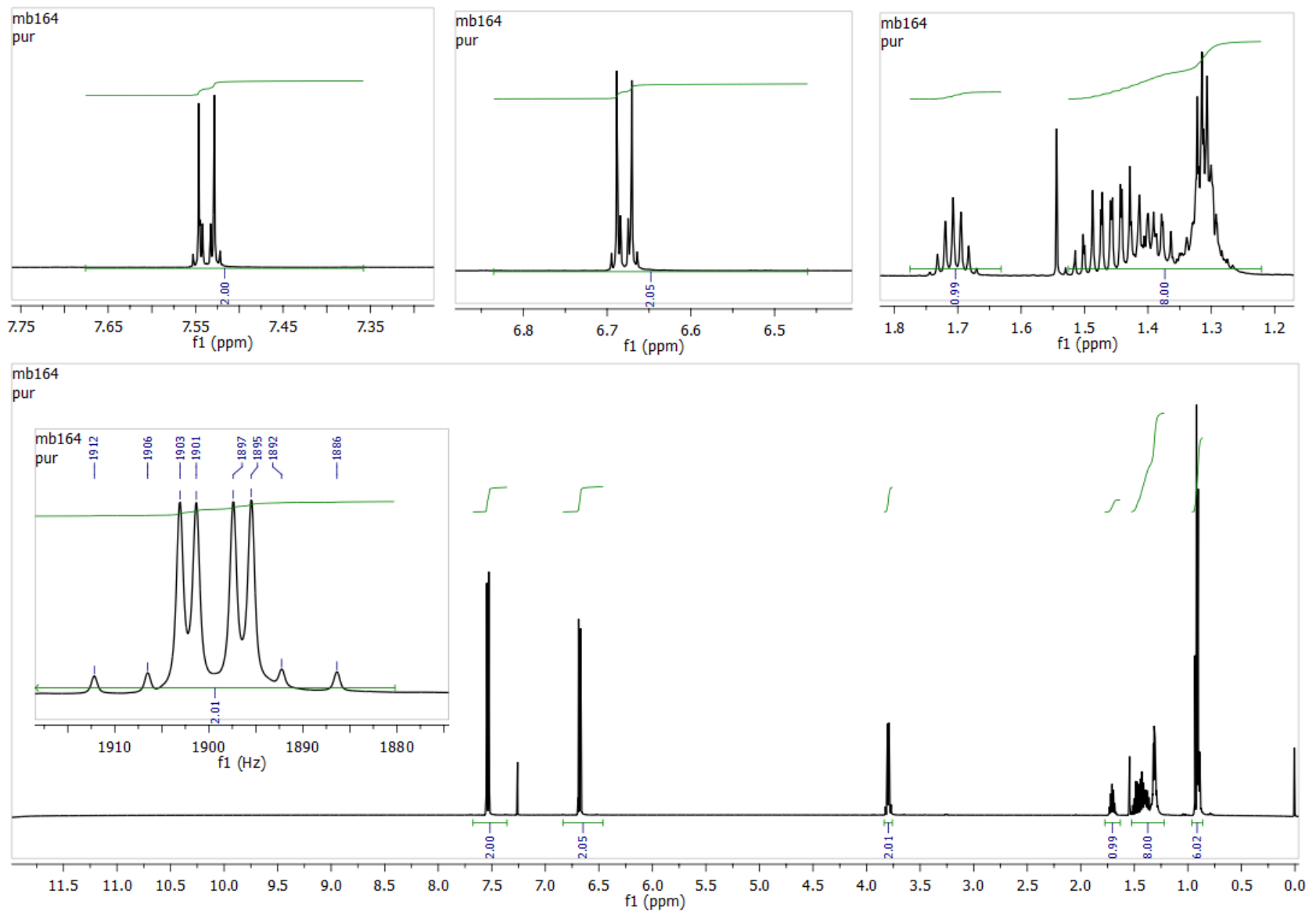


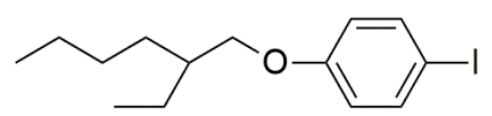

${ }^{13} \mathrm{C}$-NMR Spectrum of compound 10

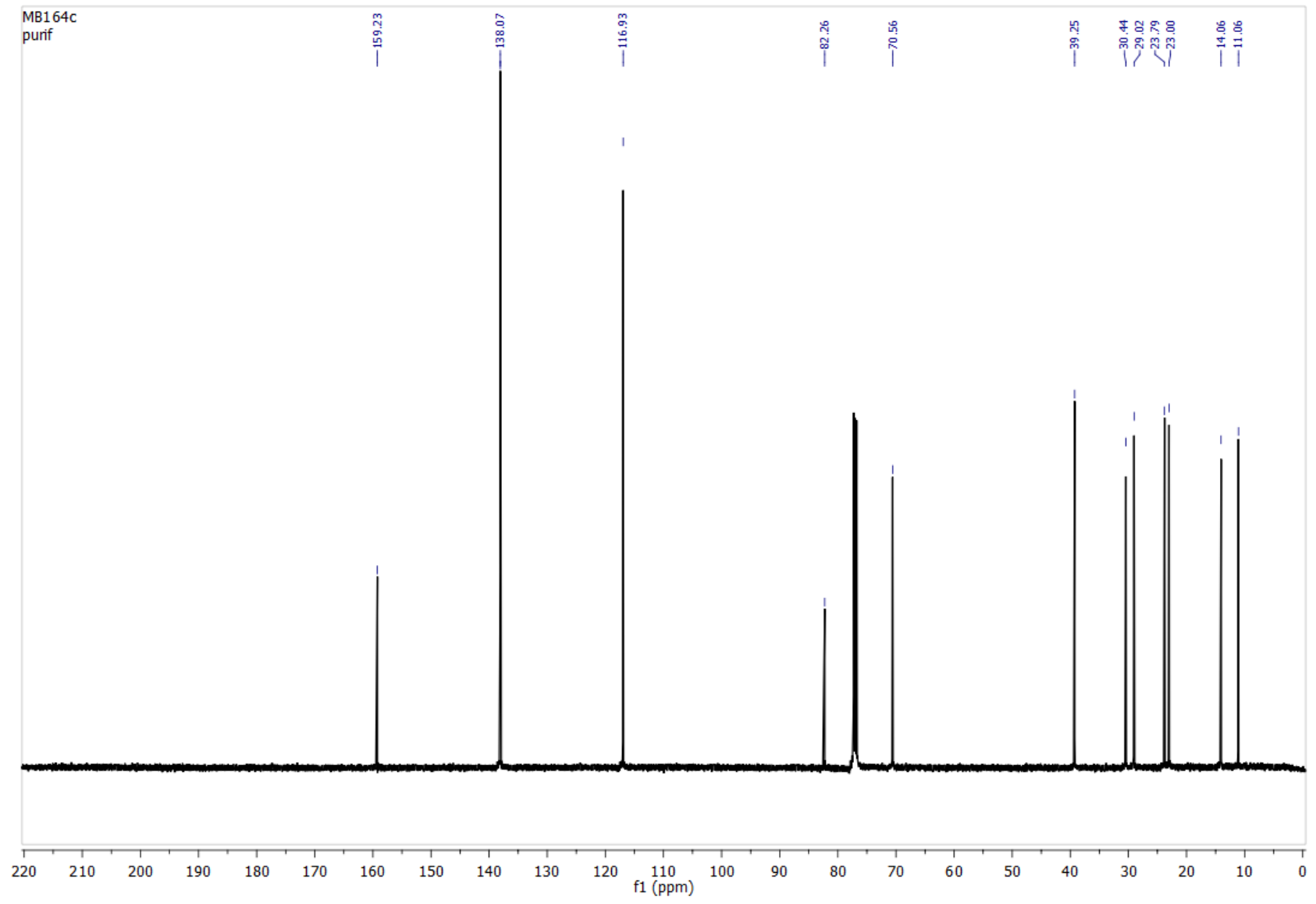




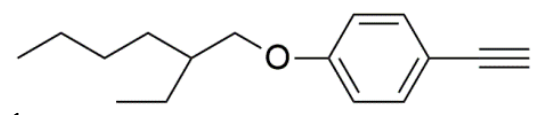

${ }^{1}$ H-NMR Spectrum of compound 2

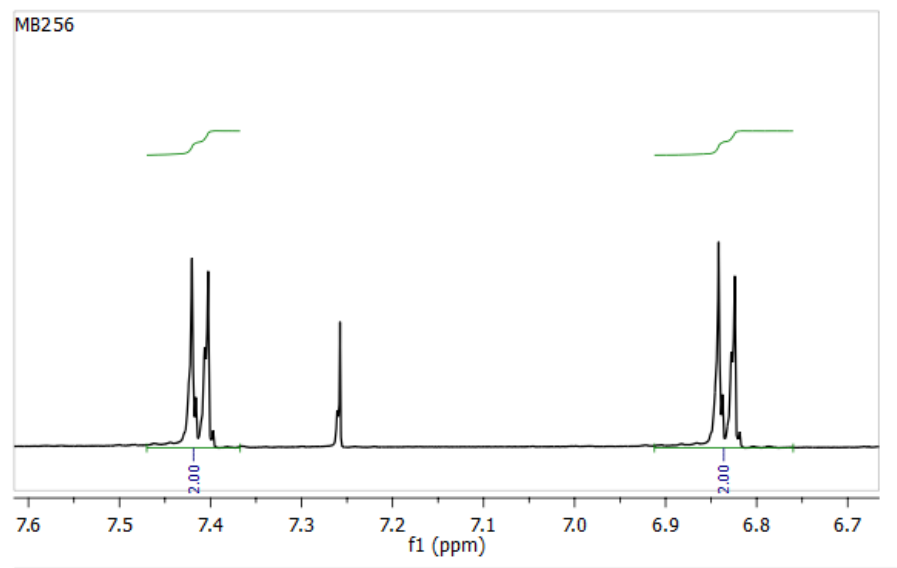

MB256

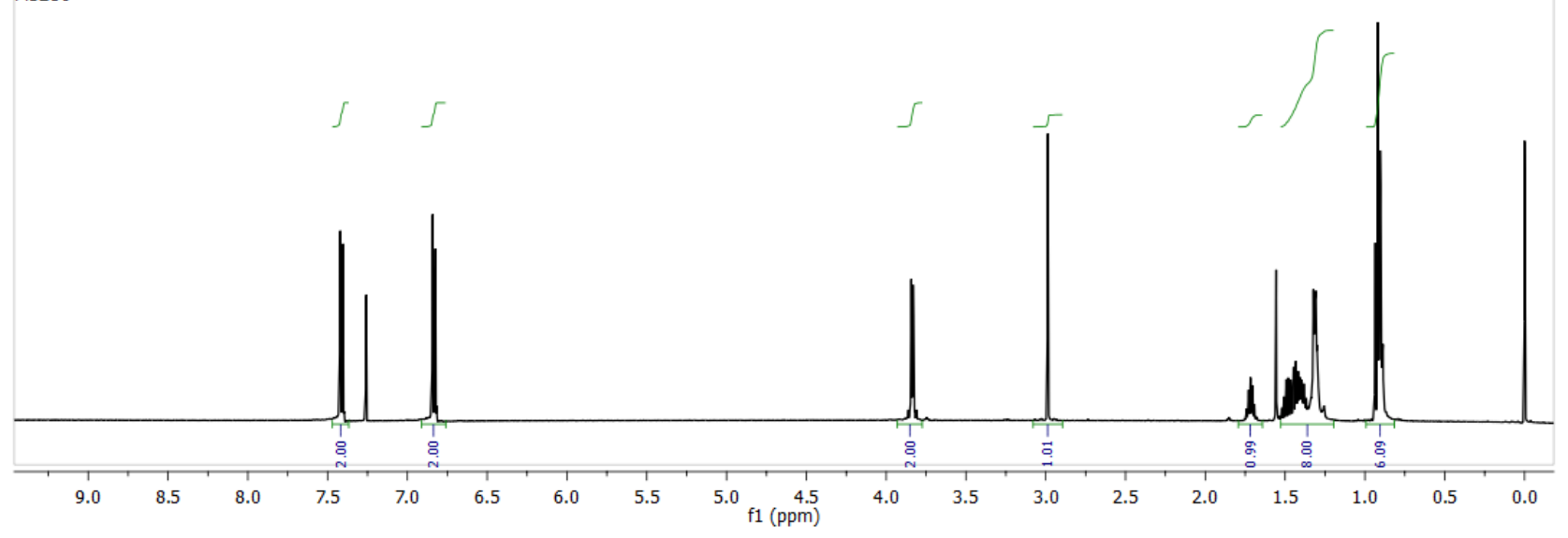




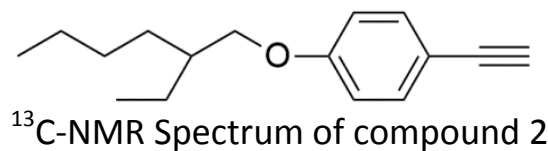

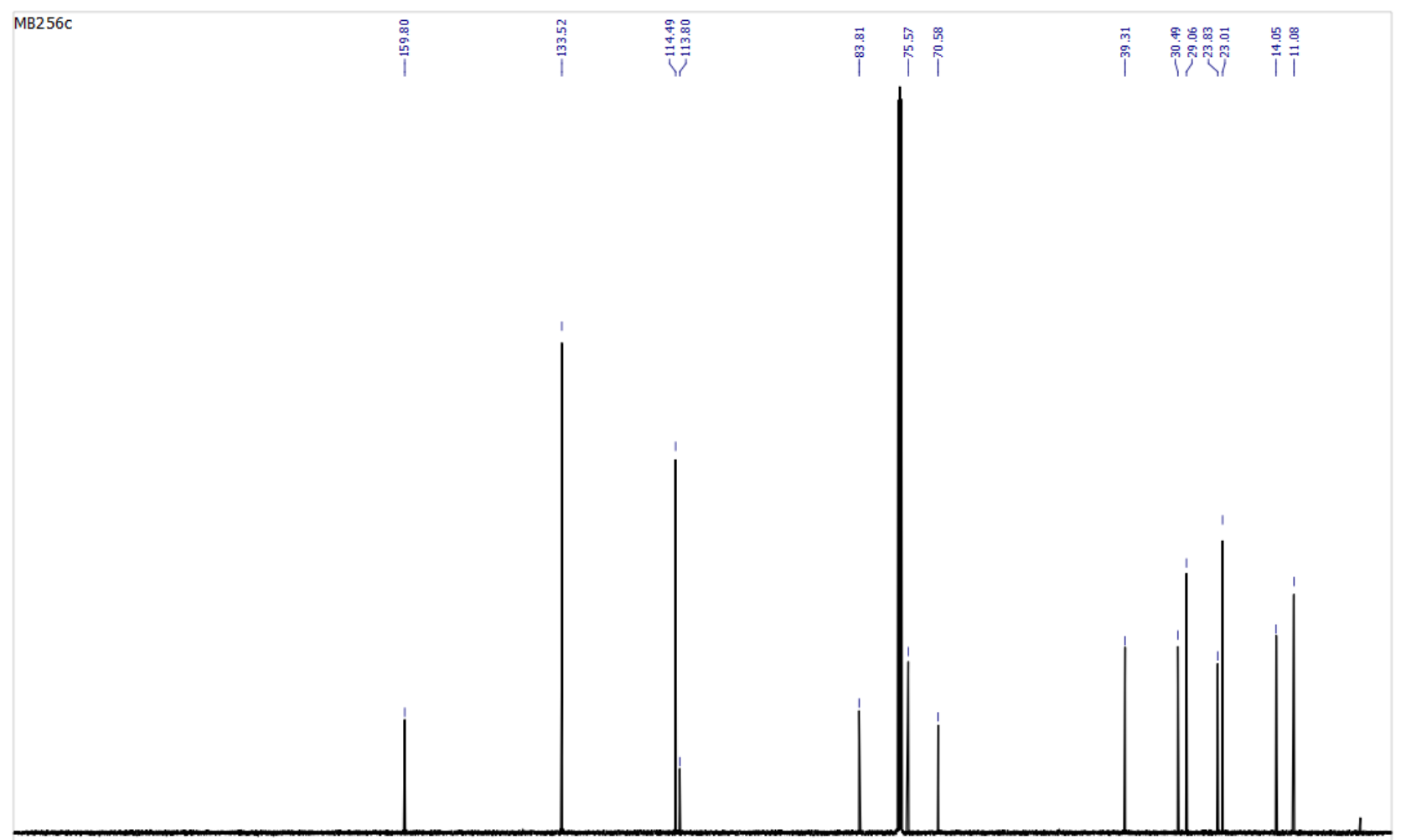

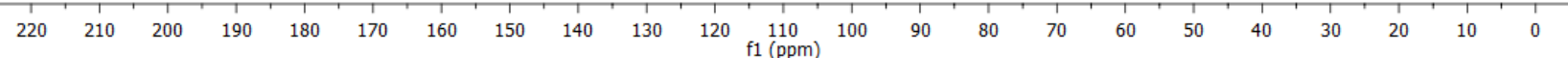




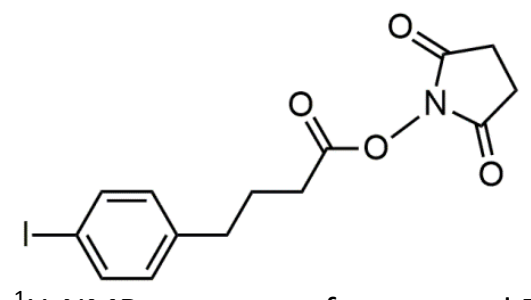

${ }^{1} \mathrm{H}-\mathrm{NMR}$ spectrum of compound $\mathbf{5}$

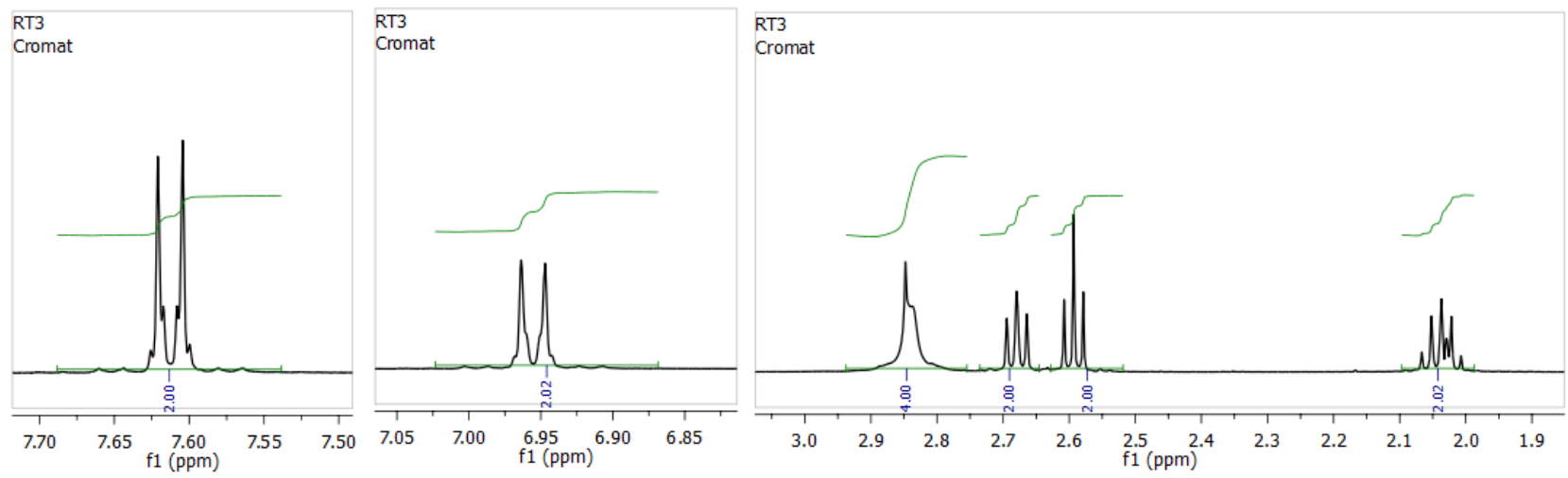

RT3

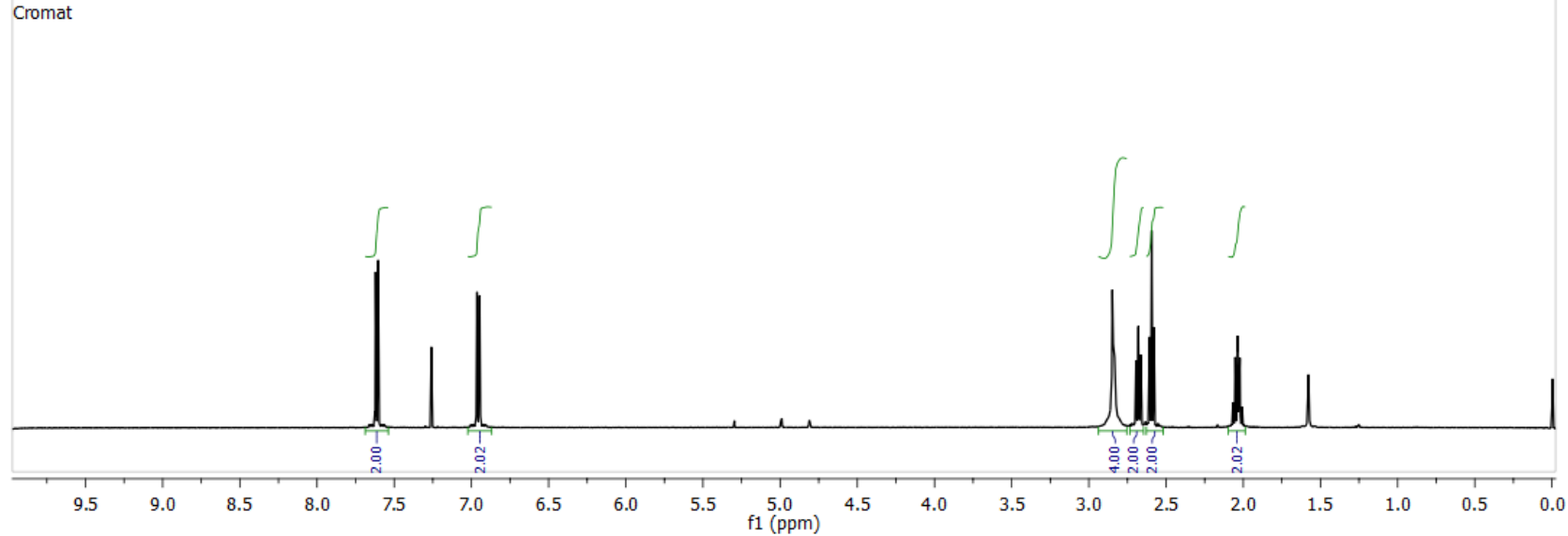




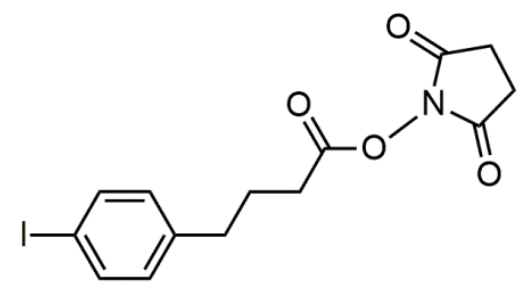

${ }^{13} \mathrm{C}$-NMR spectrum of compound 5 ,

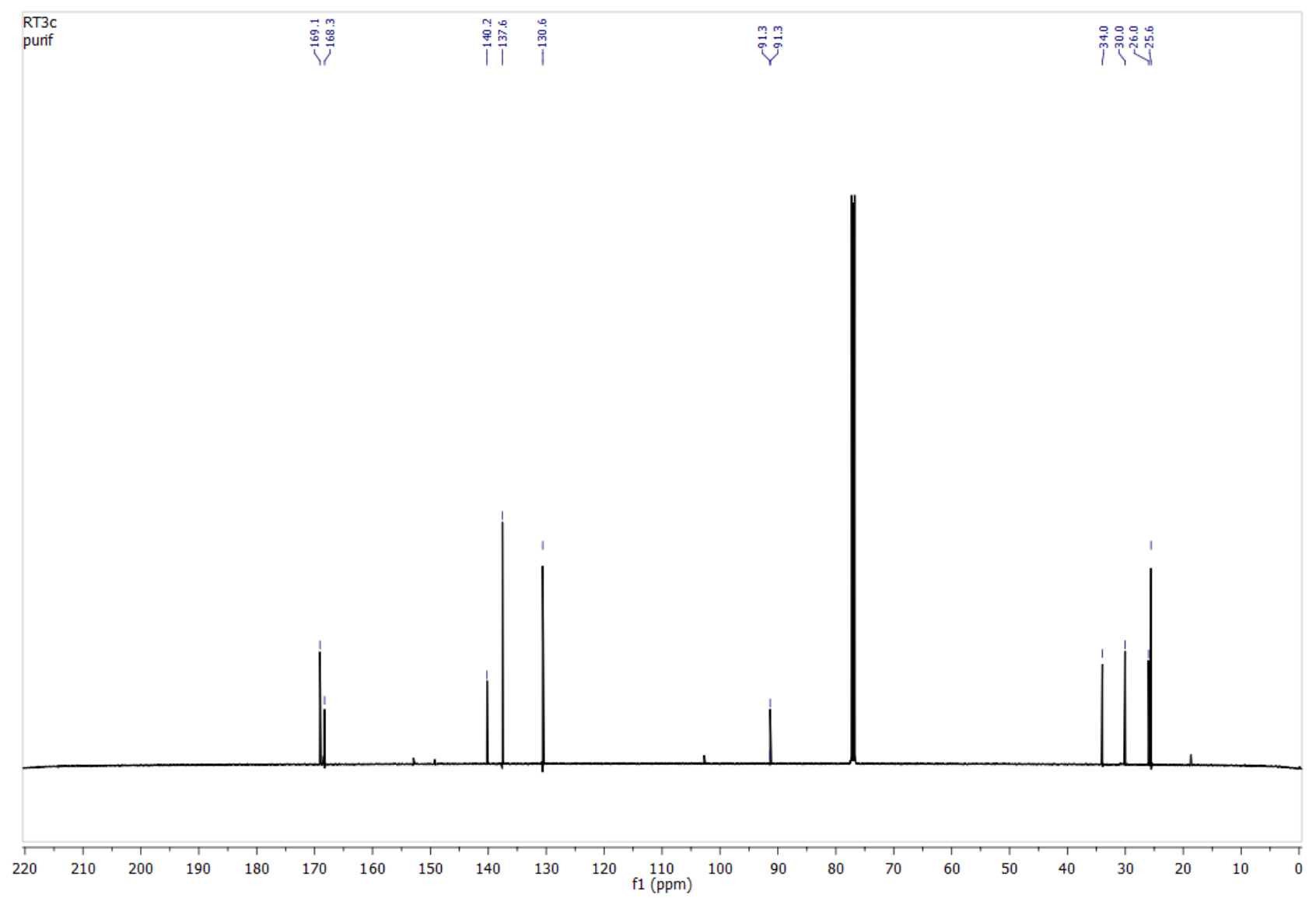


<smiles>O=[N+]([O-])c1c([N+](=O)[O-])c(Br)c2nsnc2c1Br</smiles>

${ }^{13} \mathrm{C}-\mathrm{NMR}$ spectrum of compound 6

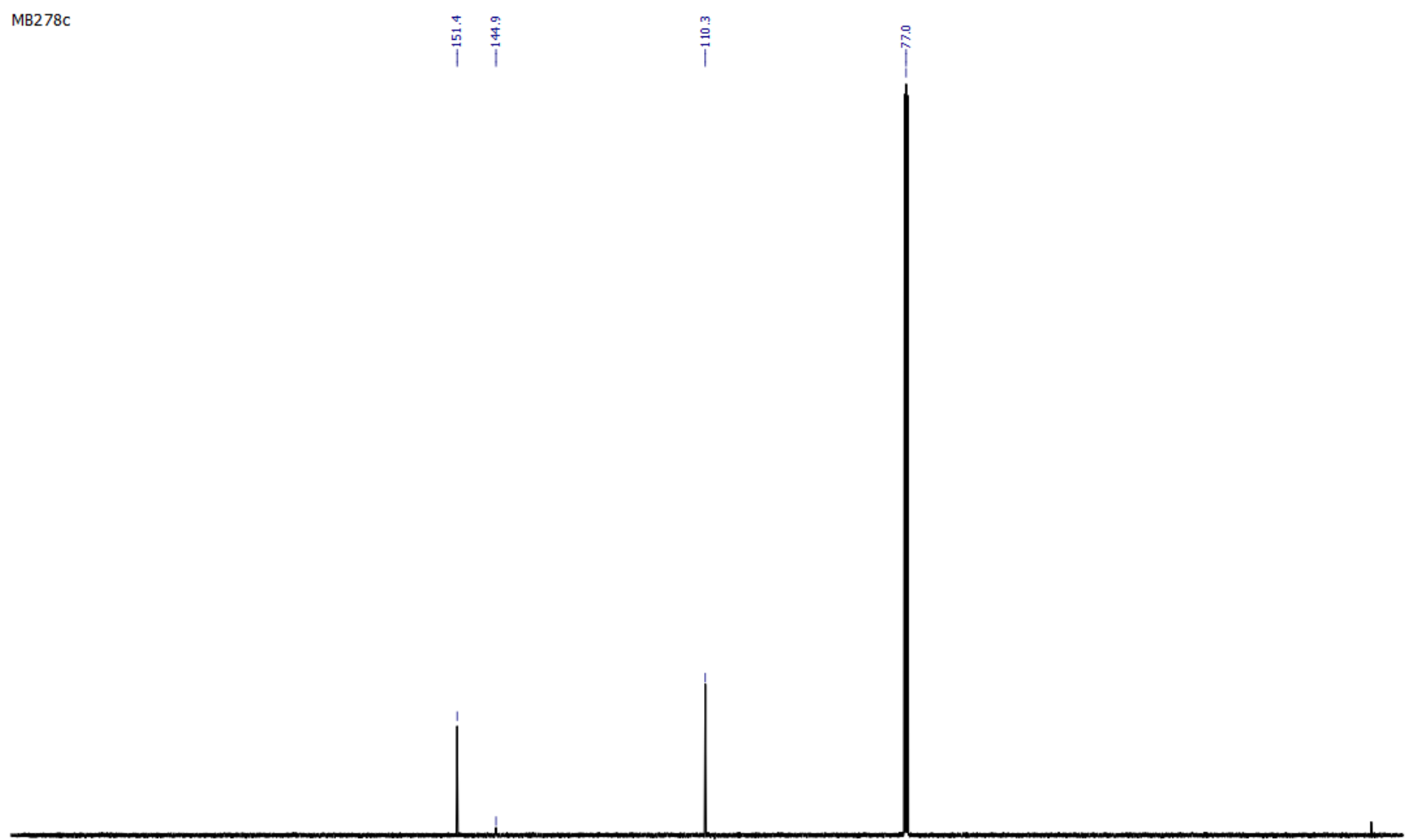

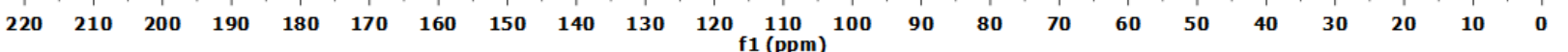




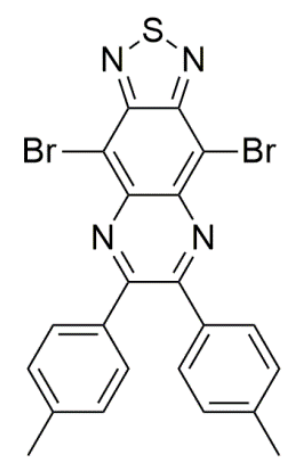

${ }^{1} \mathrm{H}$-NMR spectrum of compound 7

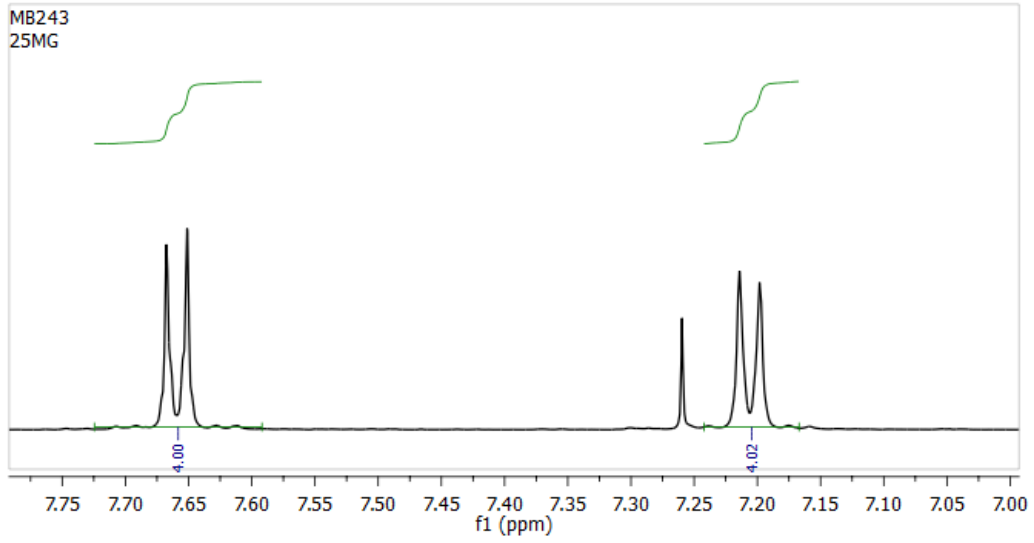

MB243

25MG

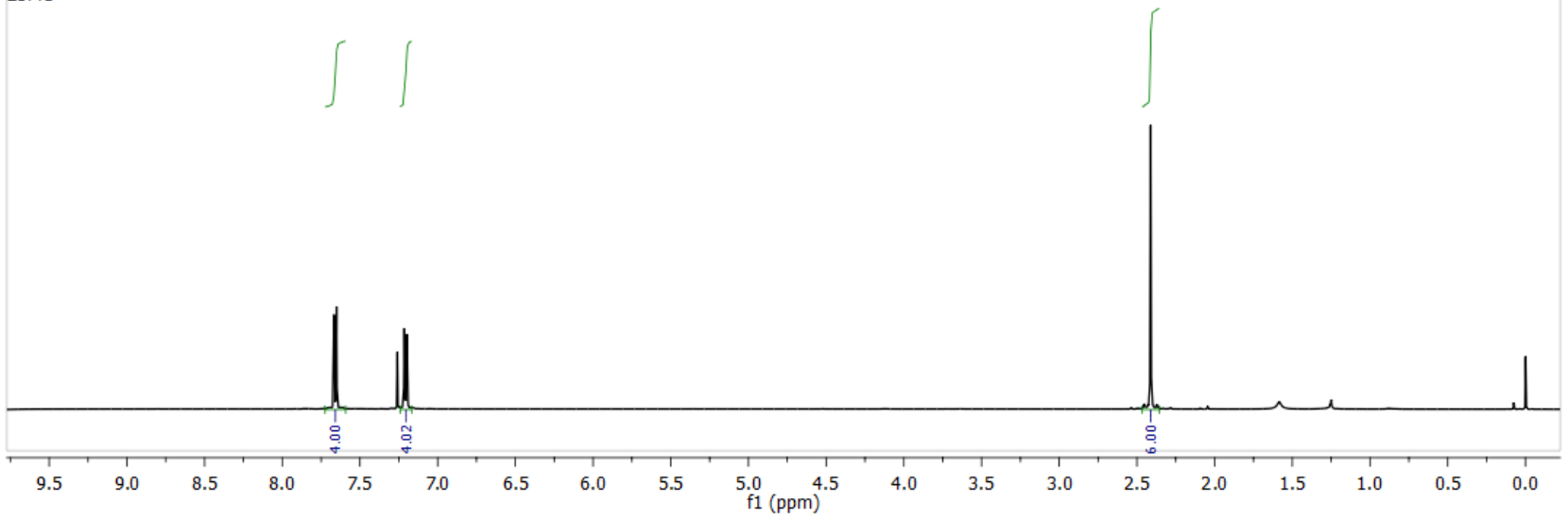



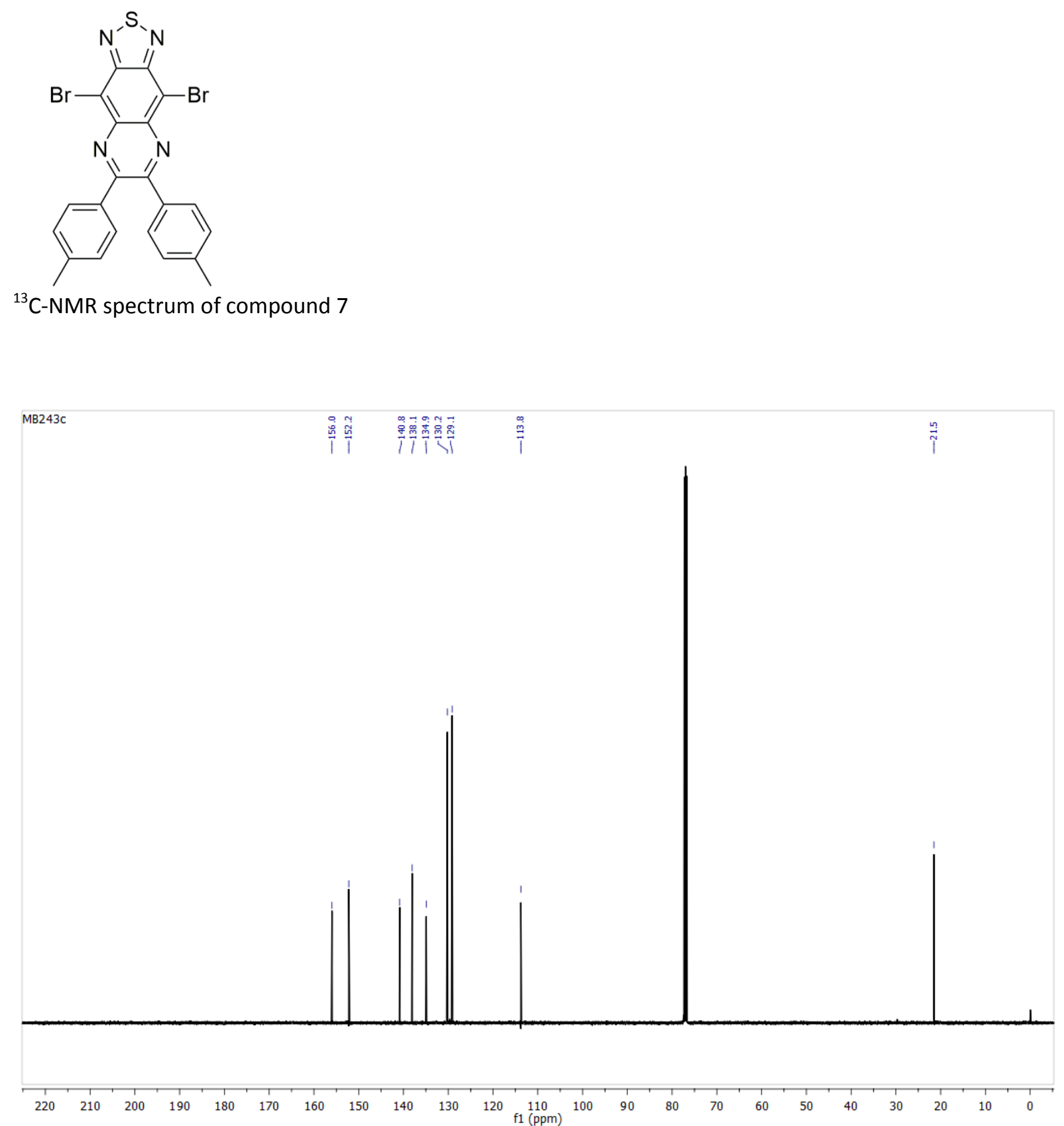


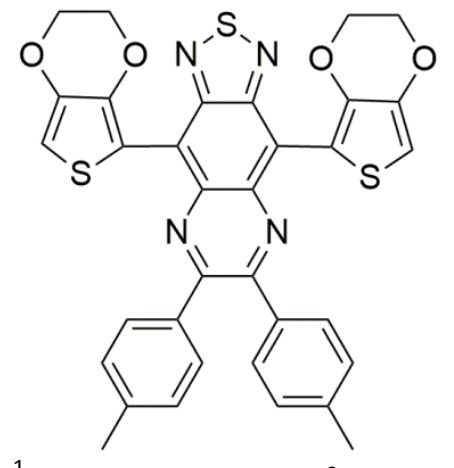

${ }^{1} \mathrm{H}$-NMR spectrum of compound 9
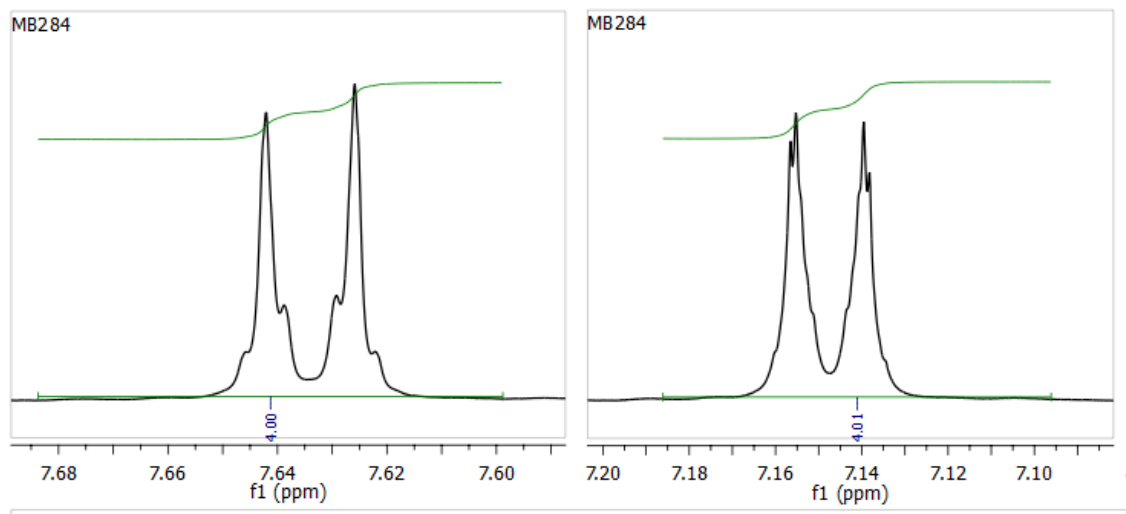

MB284

MB284

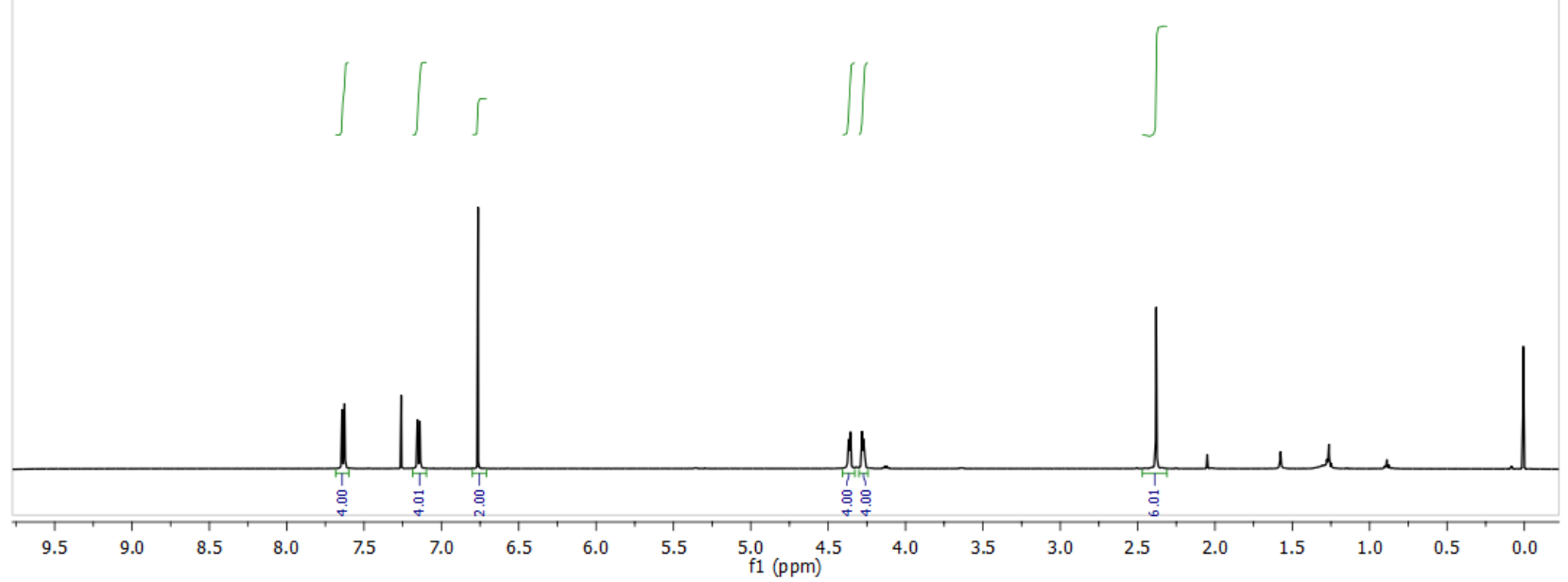




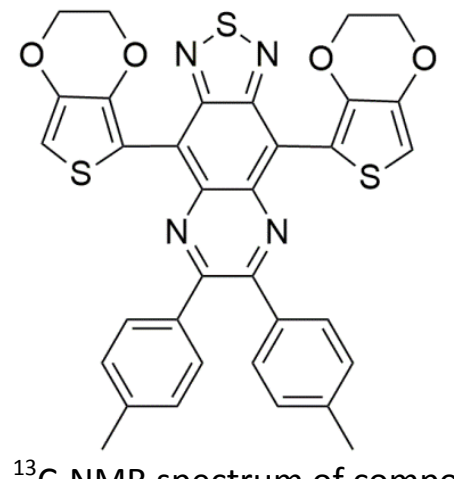

${ }^{13} \mathrm{C}$-NMR spectrum of compound 9

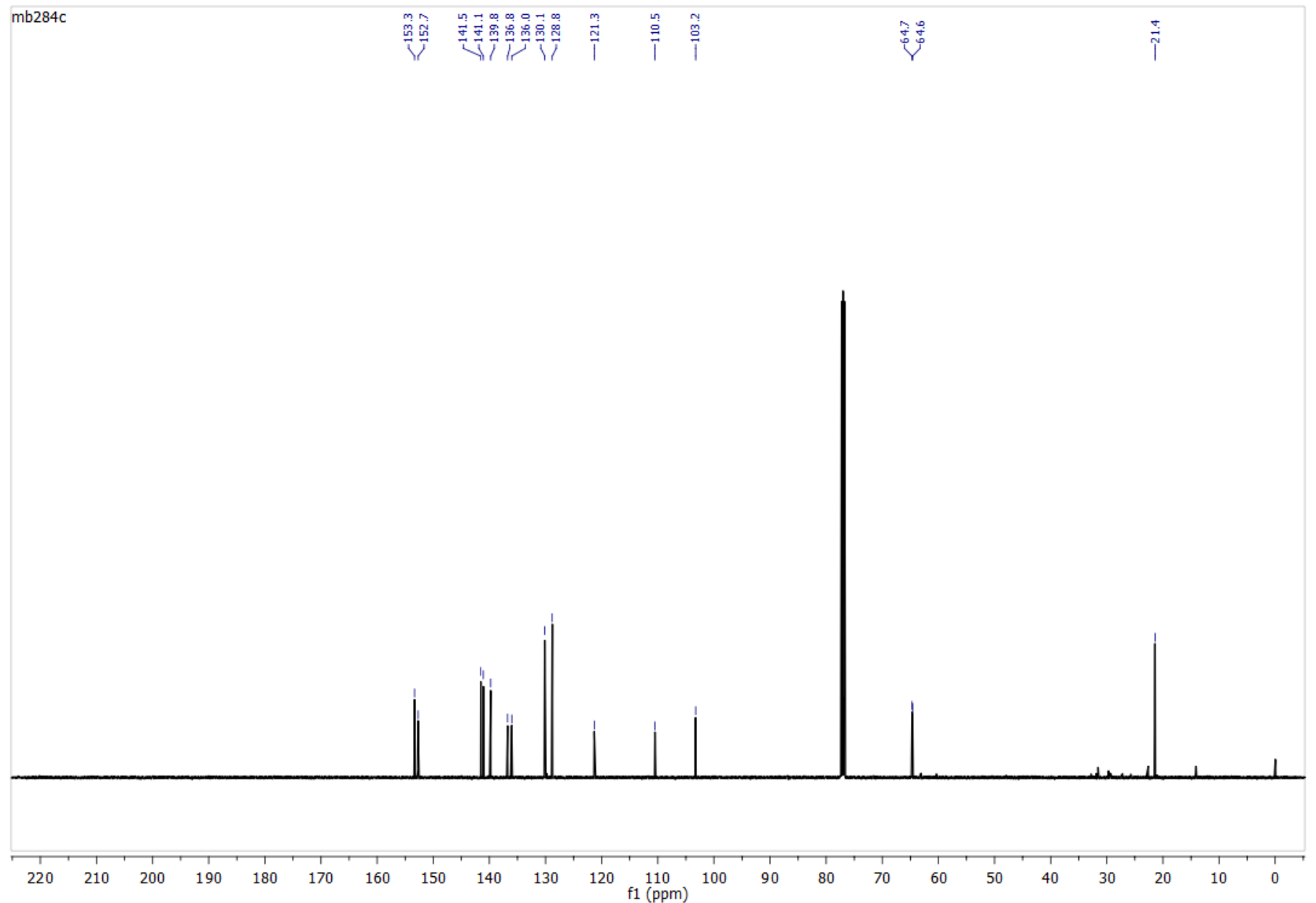




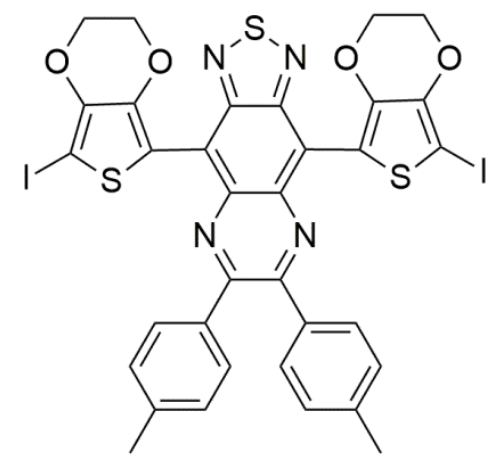

${ }^{1} \mathrm{H}-\mathrm{NMR}$ spectrum of compound 1
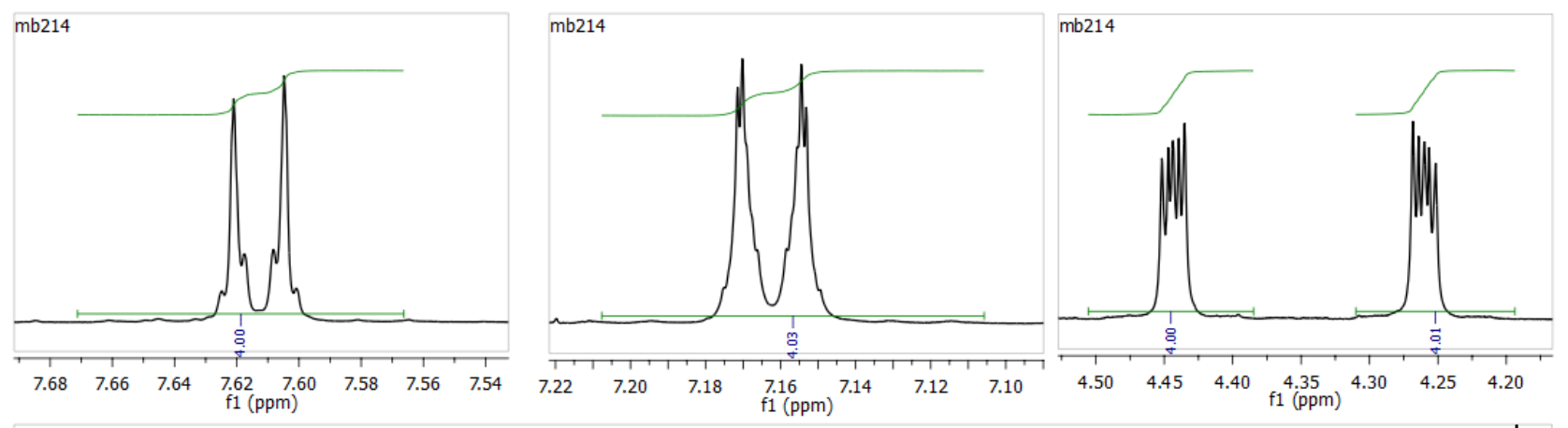
mb214

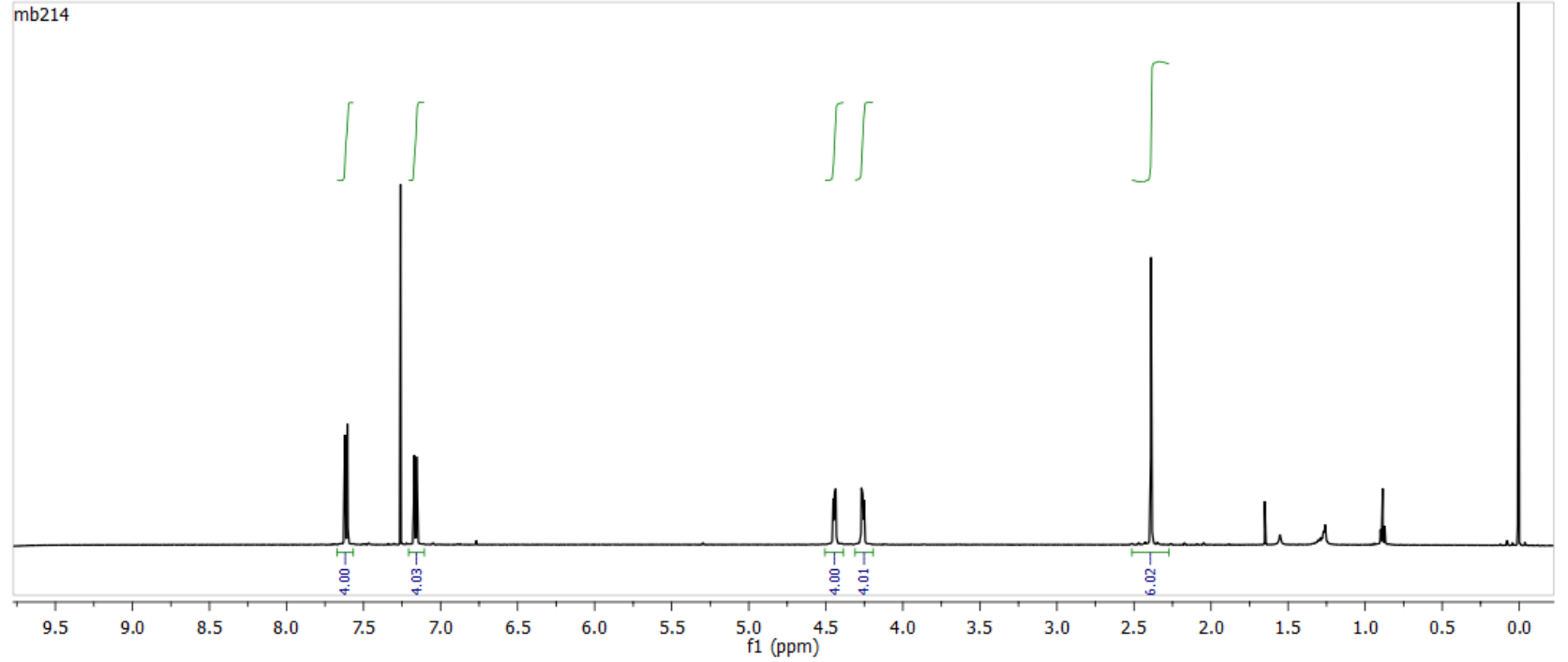




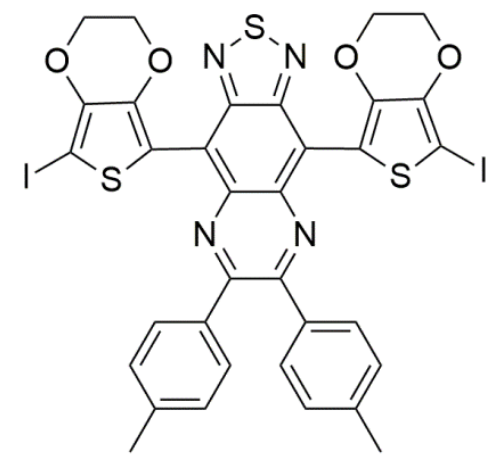

${ }^{13} \mathrm{C}$-NMR spectrum of compound 1

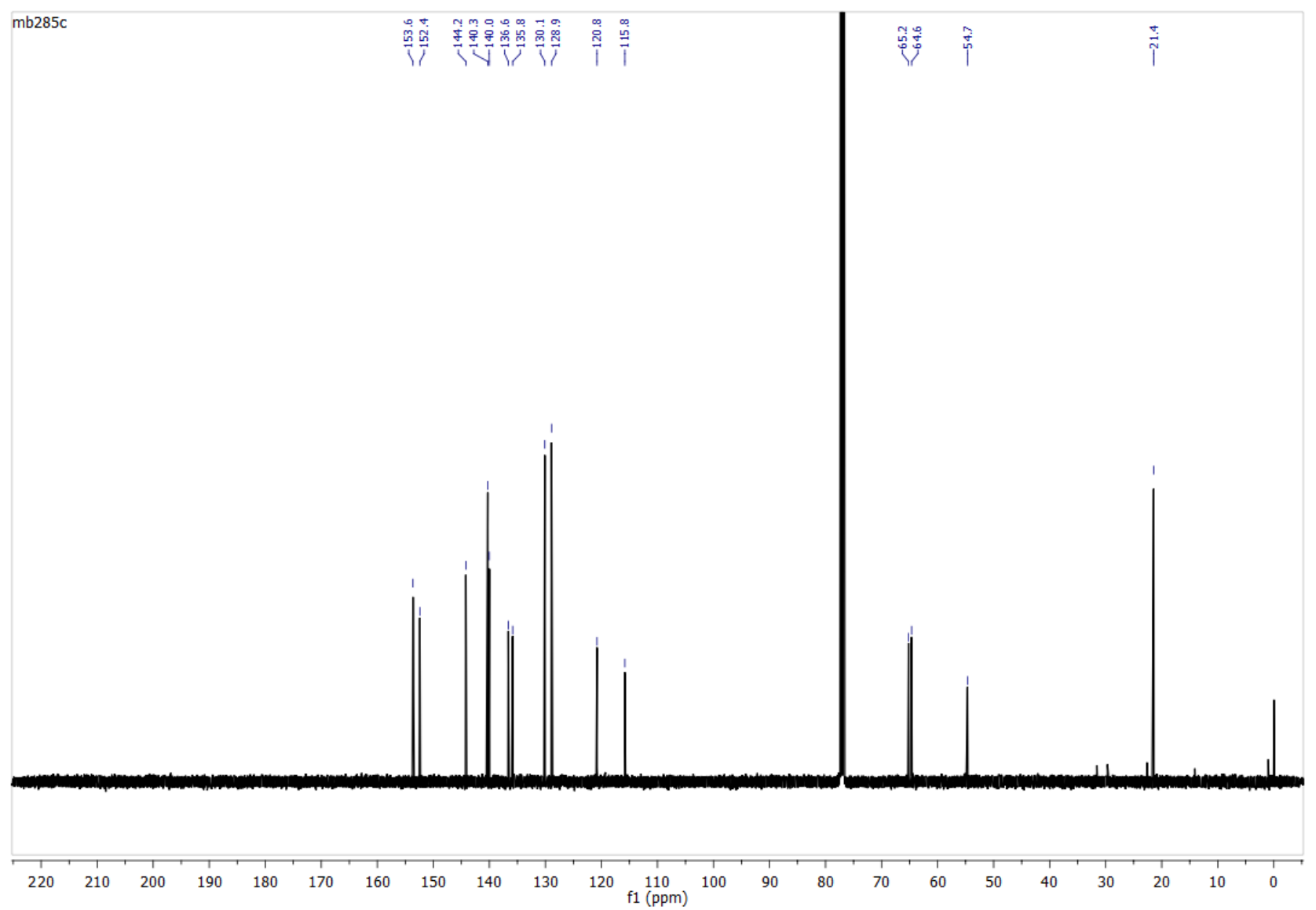




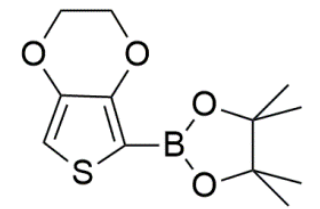

${ }^{1} \mathrm{H}-\mathrm{NMR}$ spectrum of compound 8
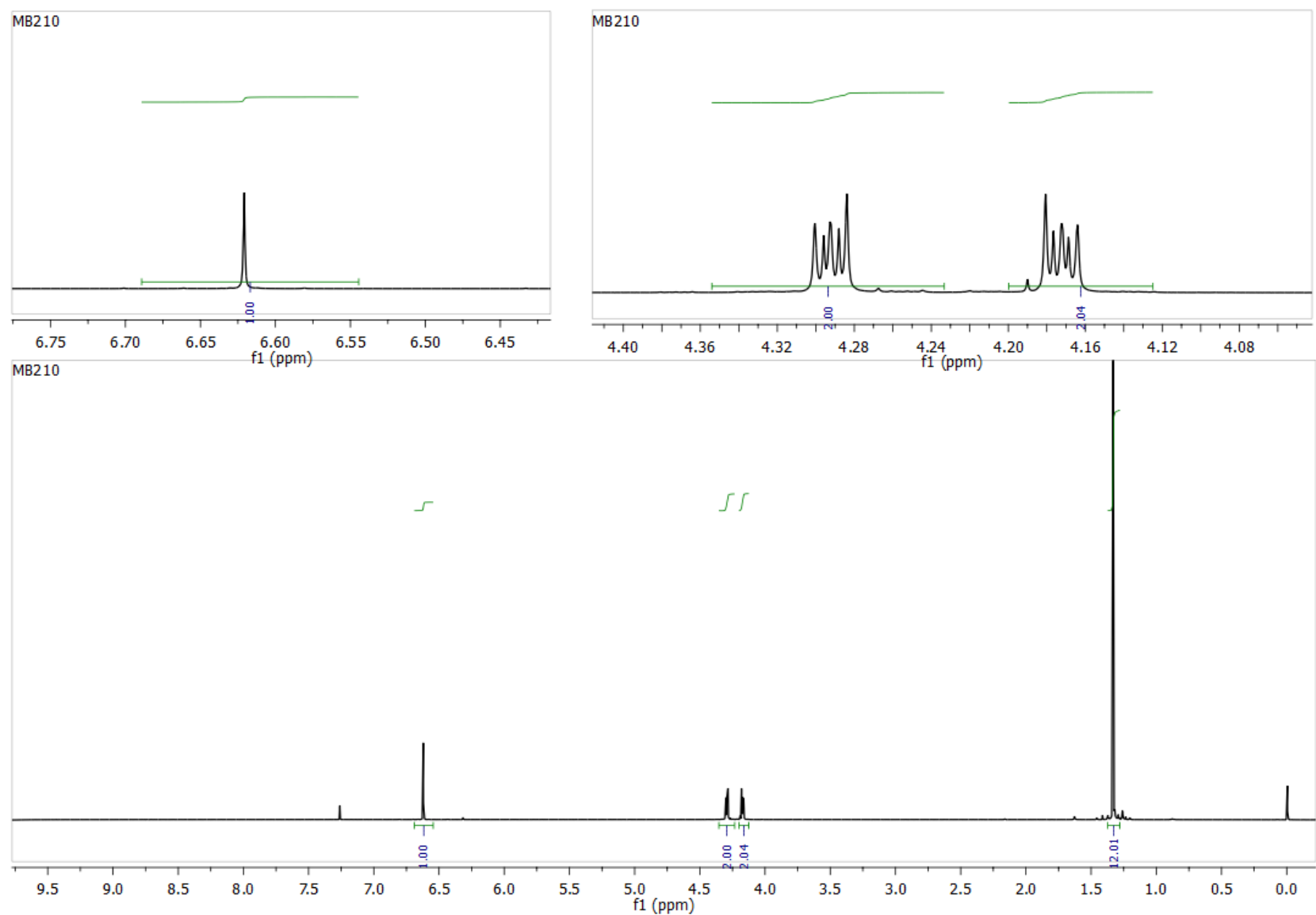


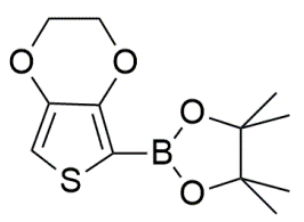

${ }^{13} \mathrm{C}$-NMR spectrum of compound 8

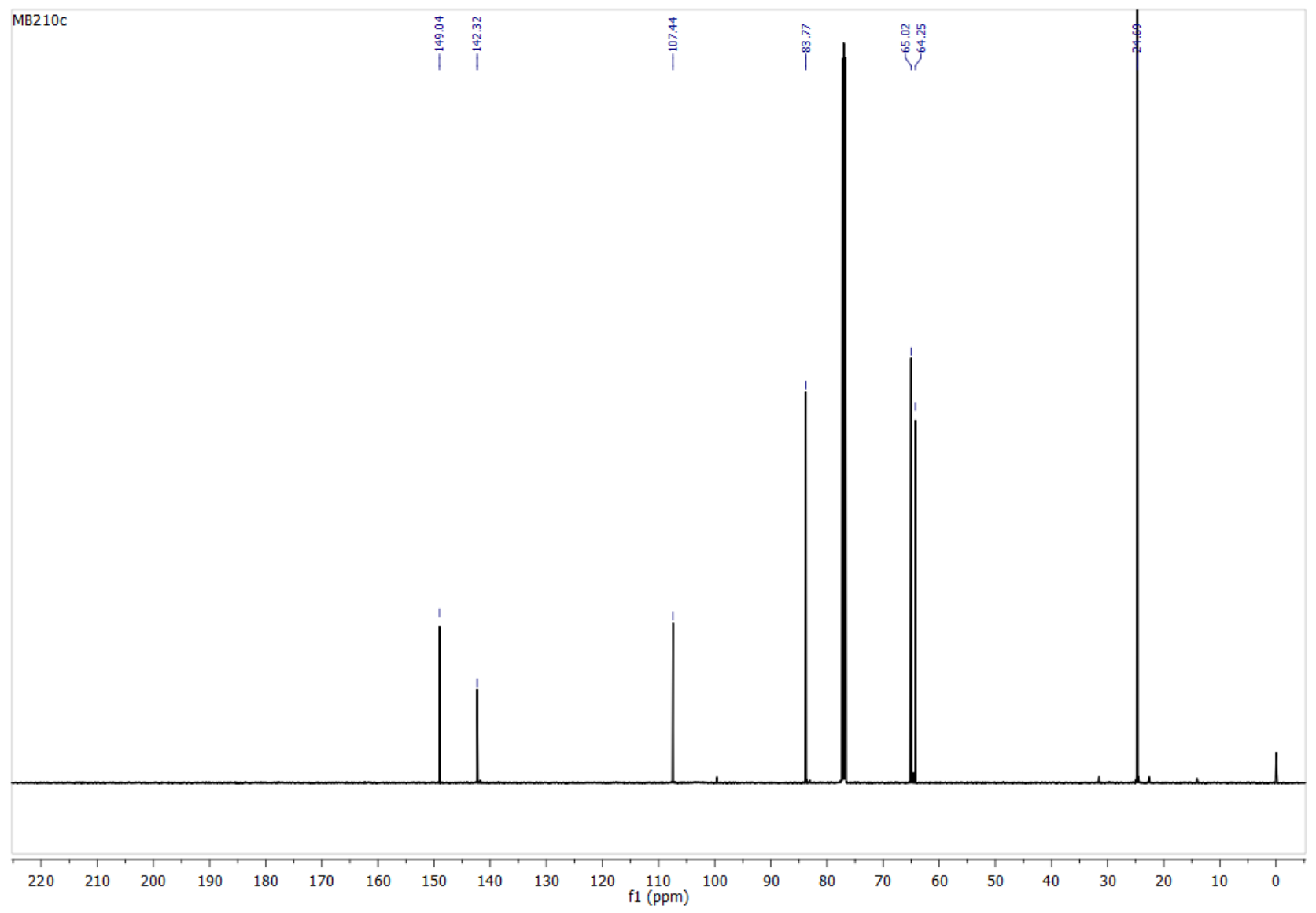




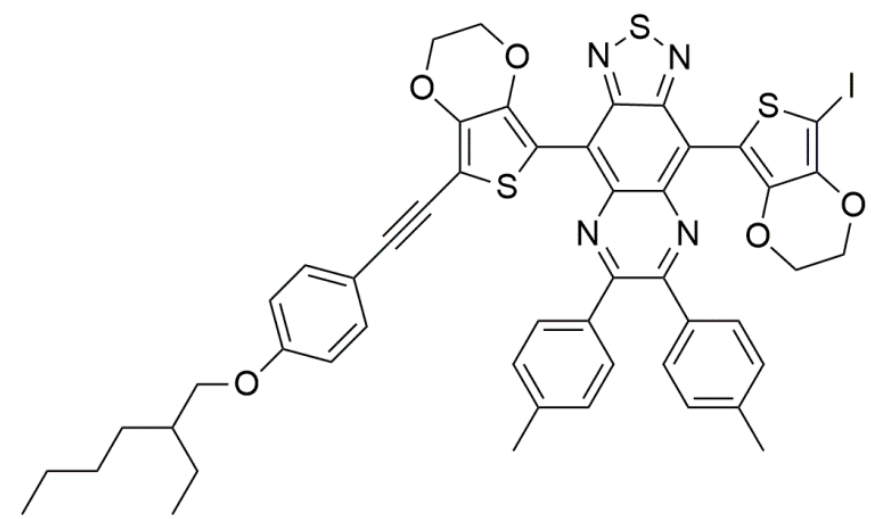

${ }^{1} \mathrm{H}$-NMR spectrum of compound 3

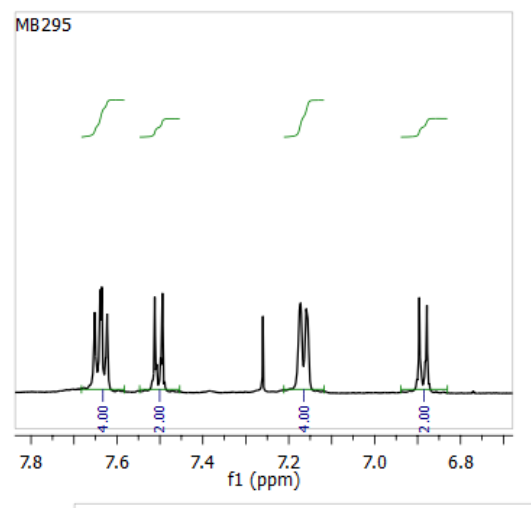

MB295

MB295

MB295
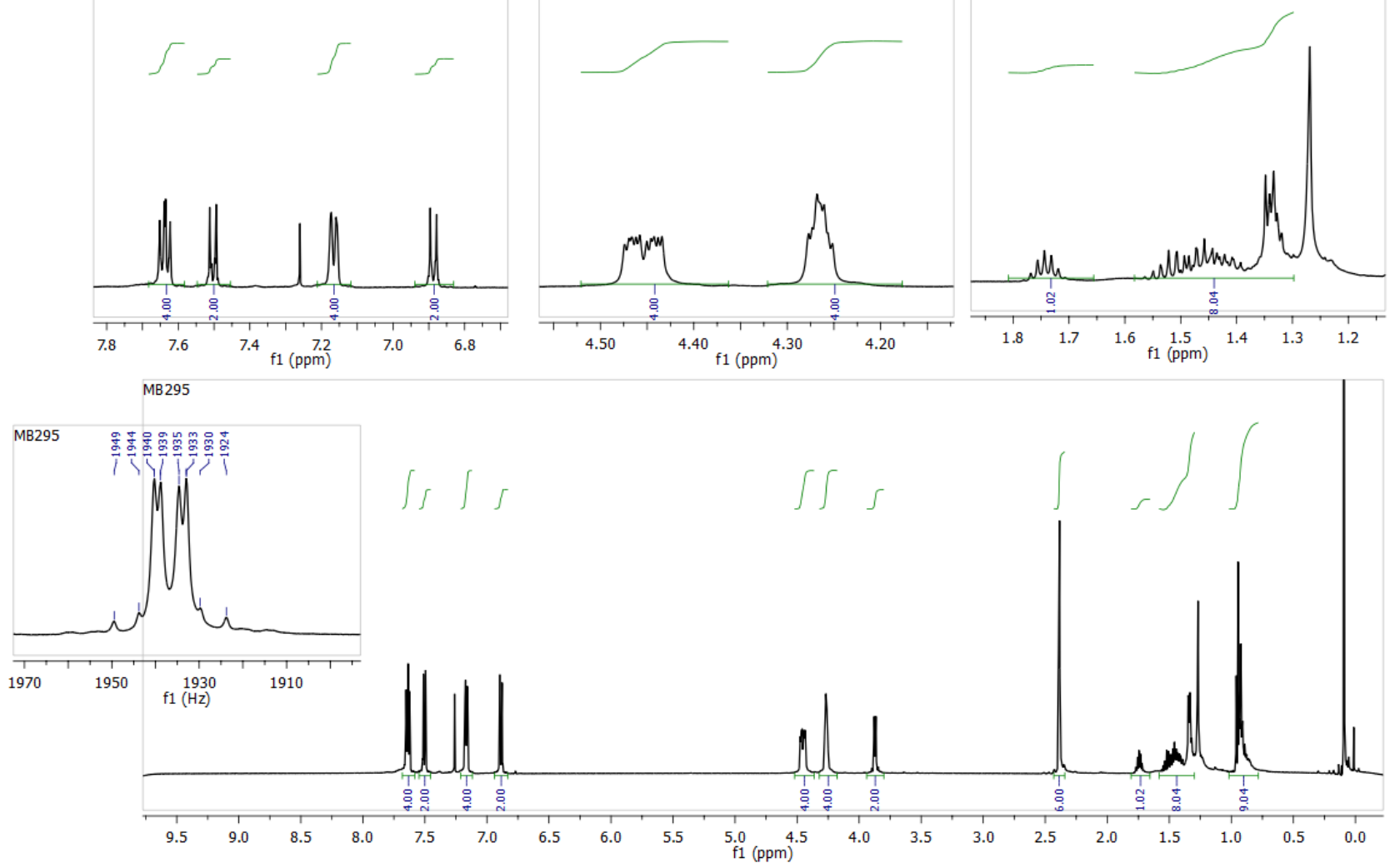


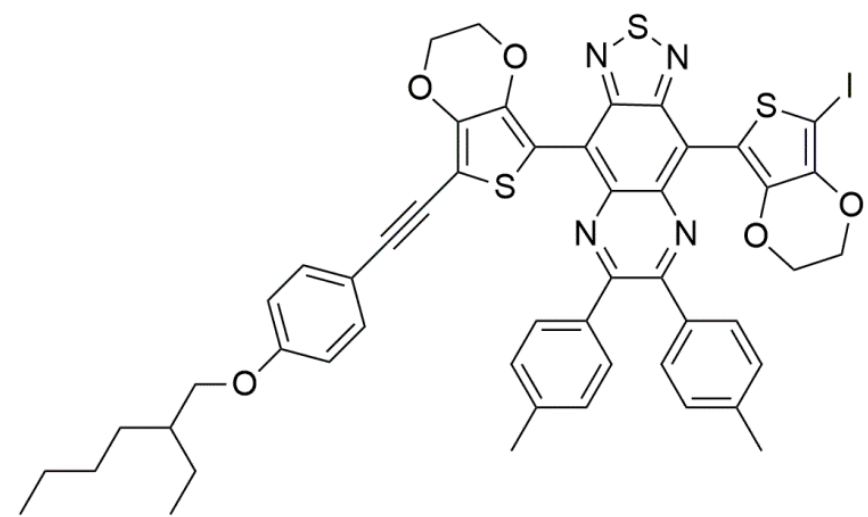

${ }^{13} \mathrm{C}$-NMR spectrum of compound 3

MB269c

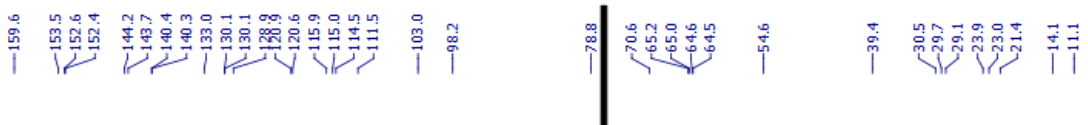

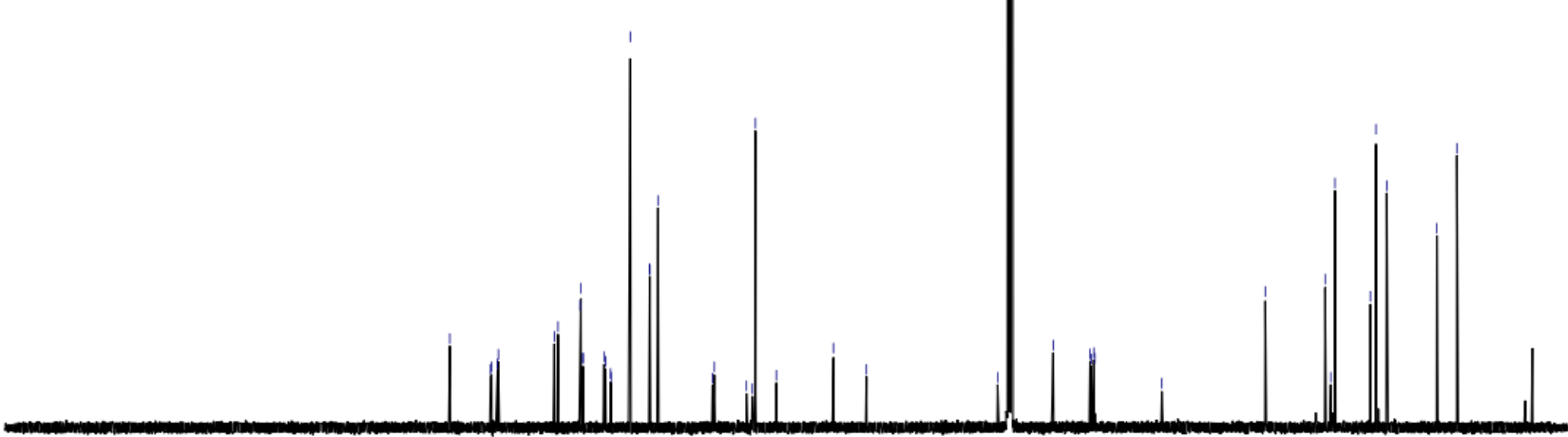

$\begin{array}{lllllllllllllllllllllllll}220 & 210 & 200 & 190 & 180 & 170 & 160 & 150 & 140 & 130 & 120 & 110 & 100 & 90 & 80 & 70 & 60 & 50 & 40 & 30 & 20 & 10 & 0\end{array}$ 


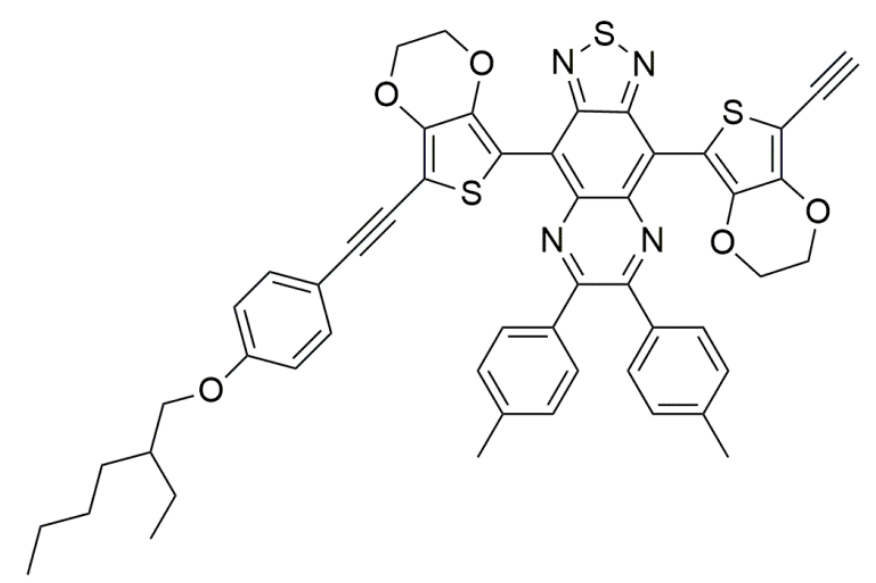

${ }^{1} \mathrm{H}-\mathrm{NMR}$ spectrum of compound 4

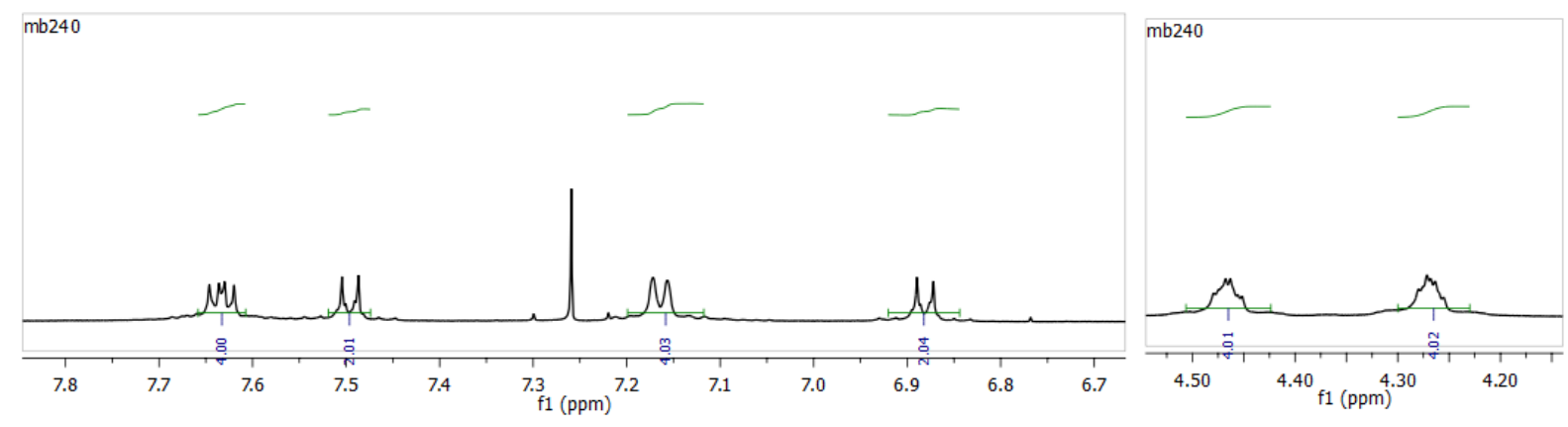

mb240

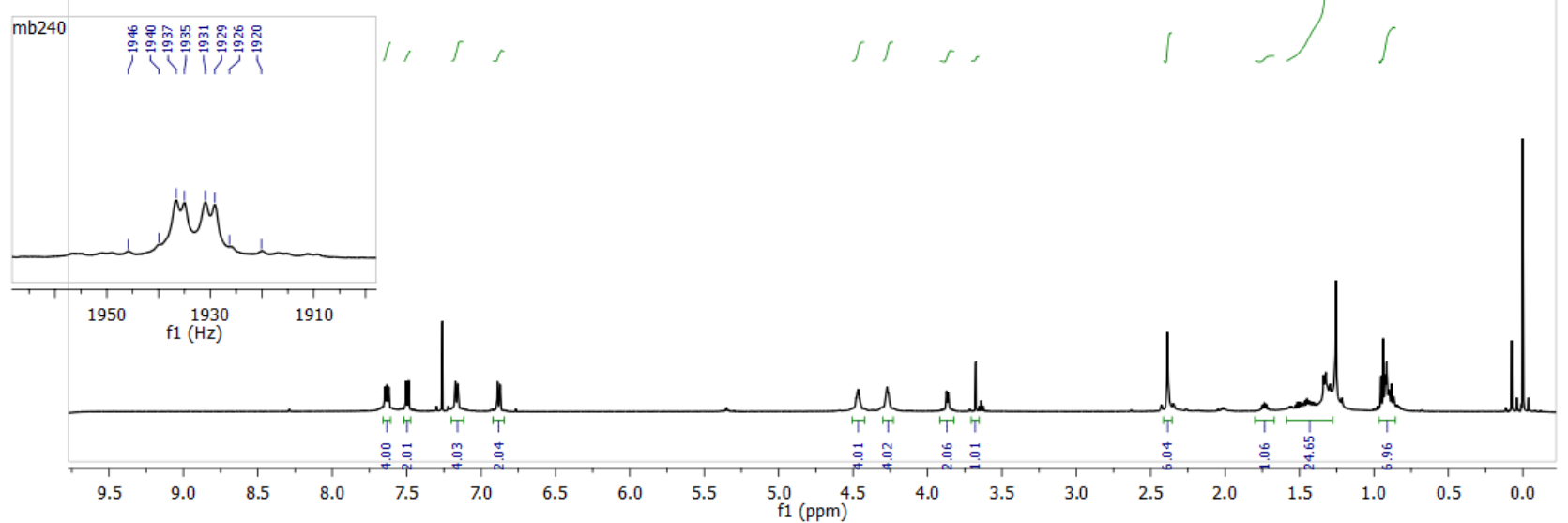




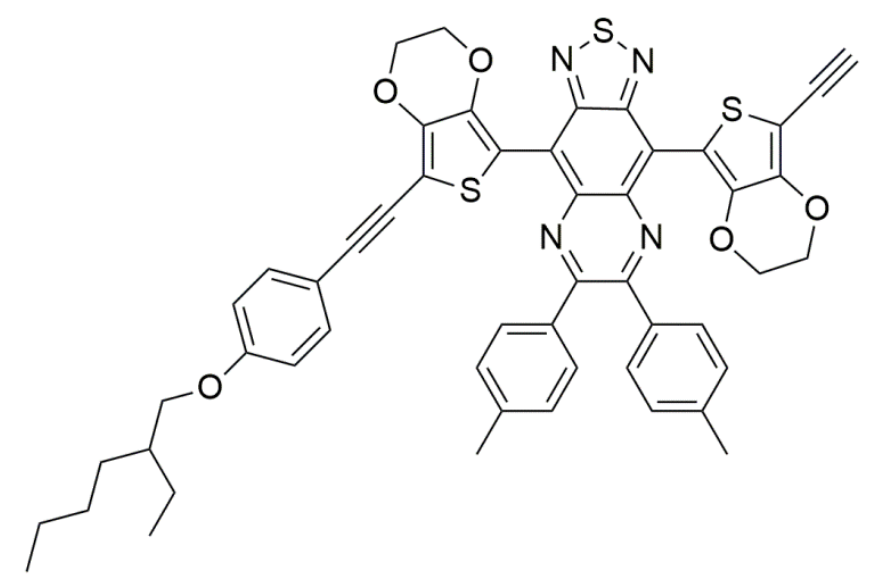

${ }^{13}$ C-NMR spectrum of compound 4

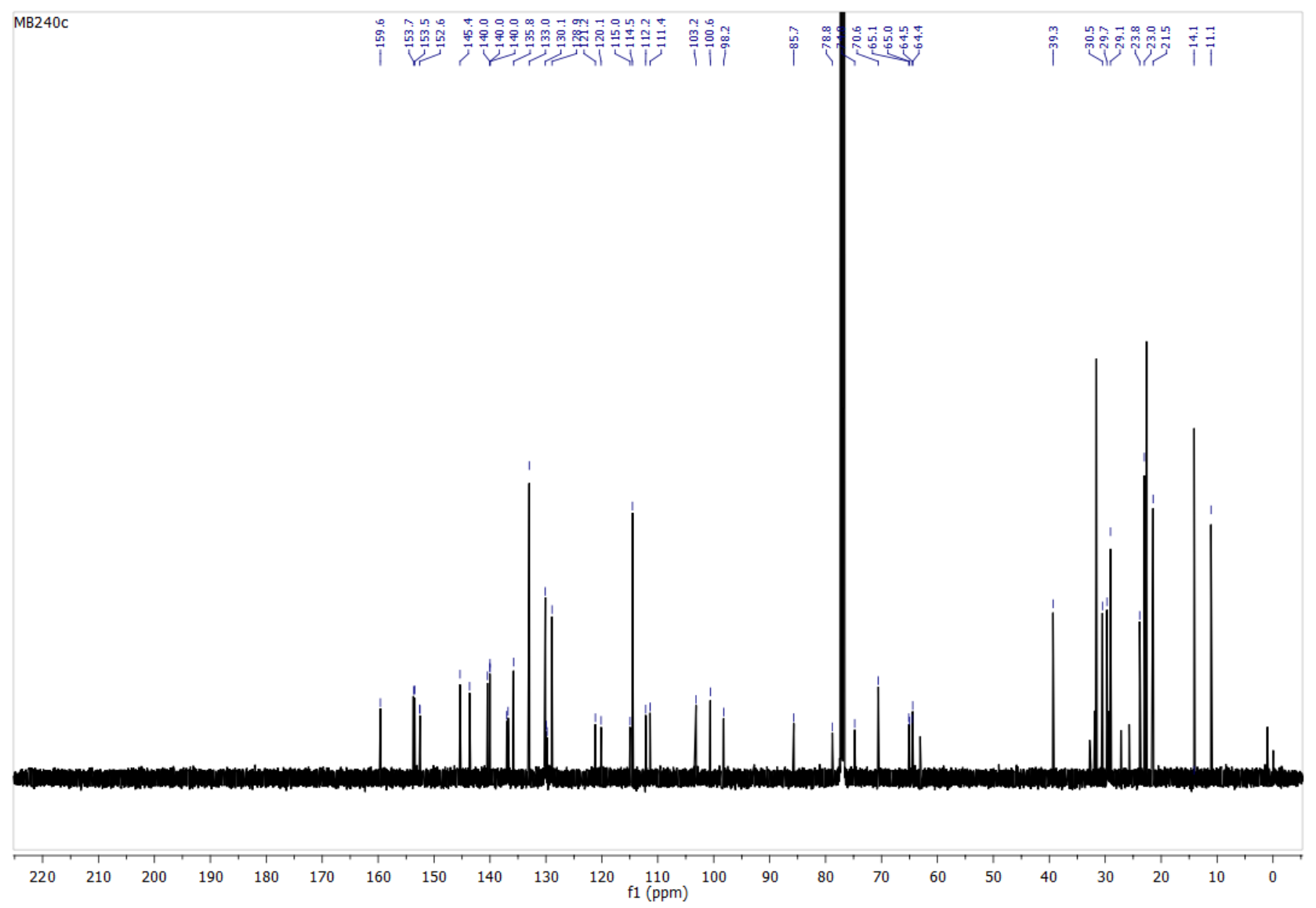




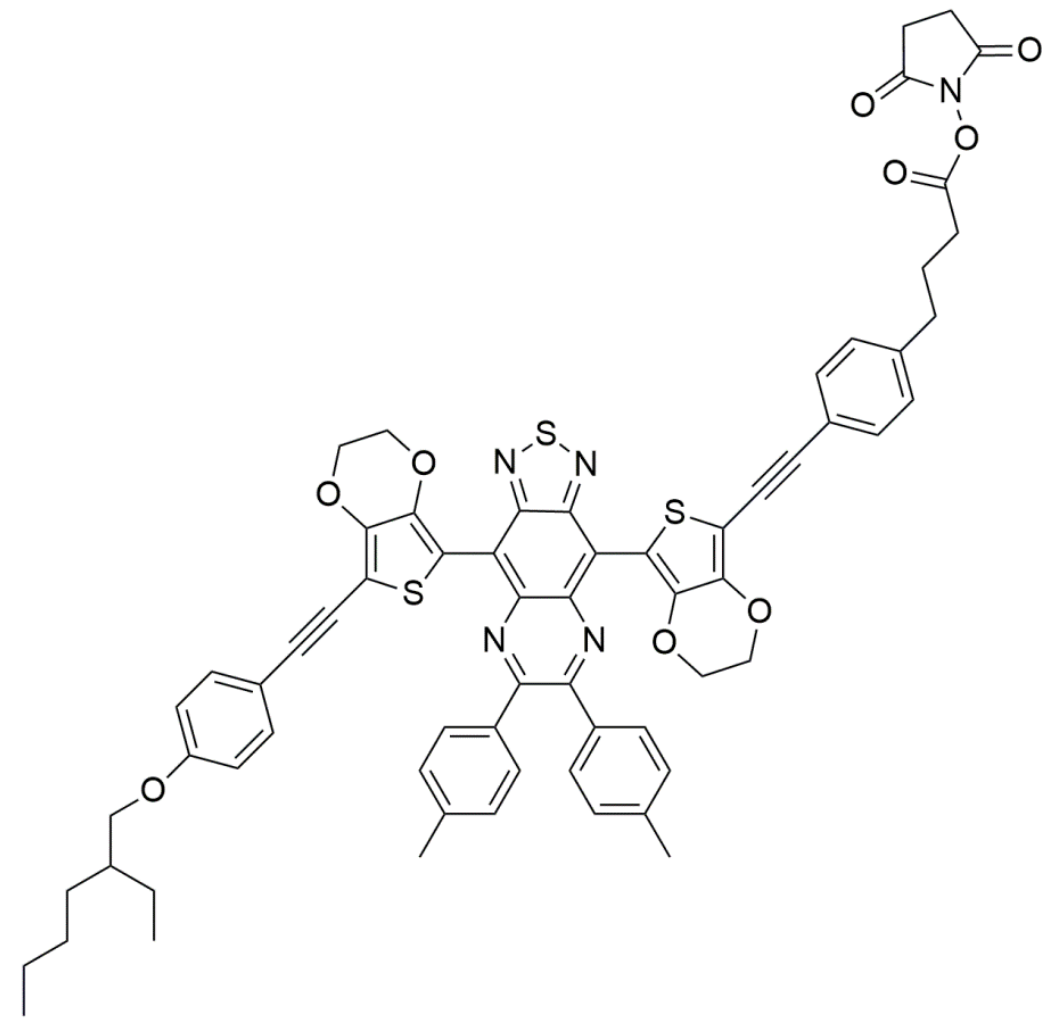

${ }^{1} \mathrm{H}$-NMR spectrum of AE800
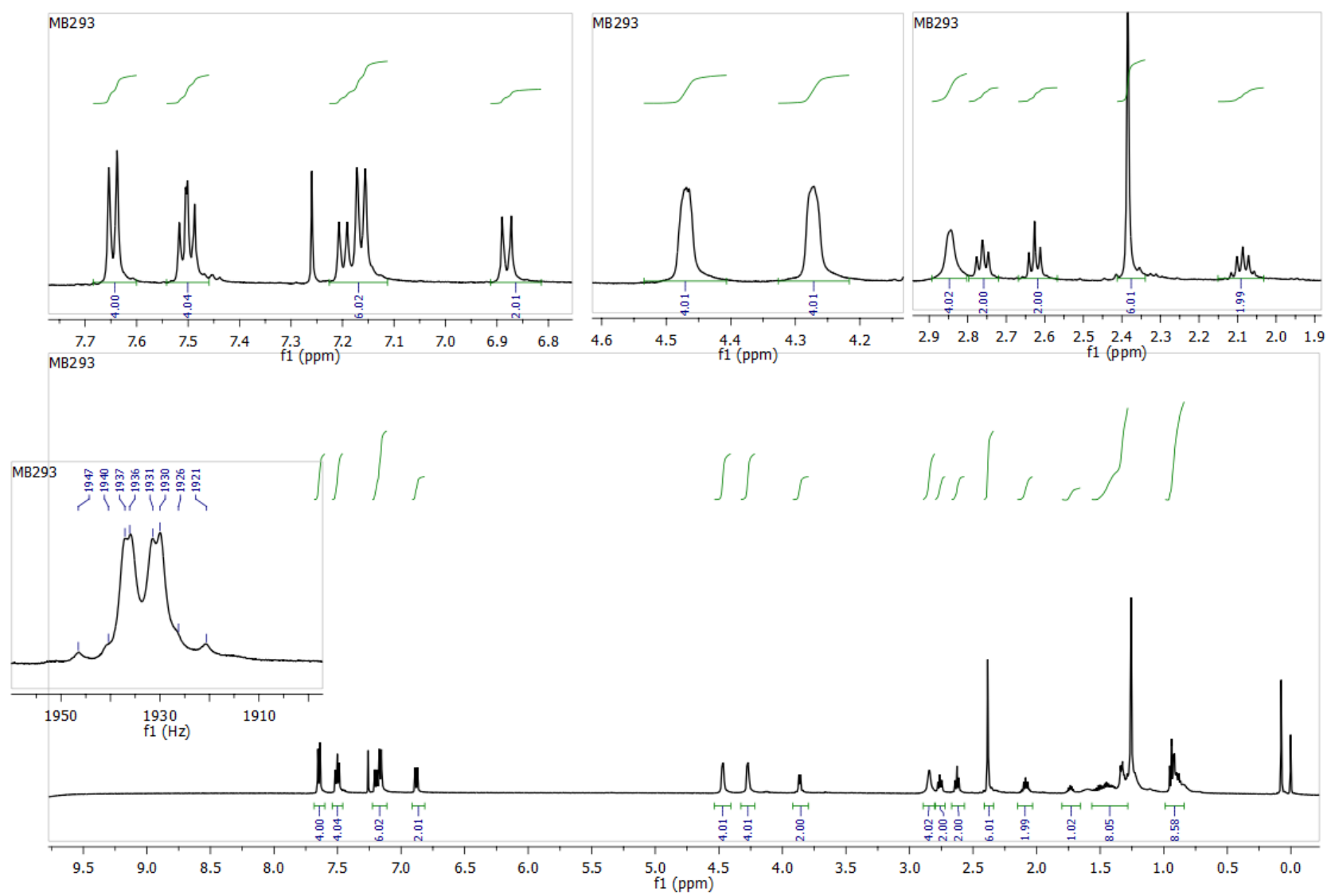


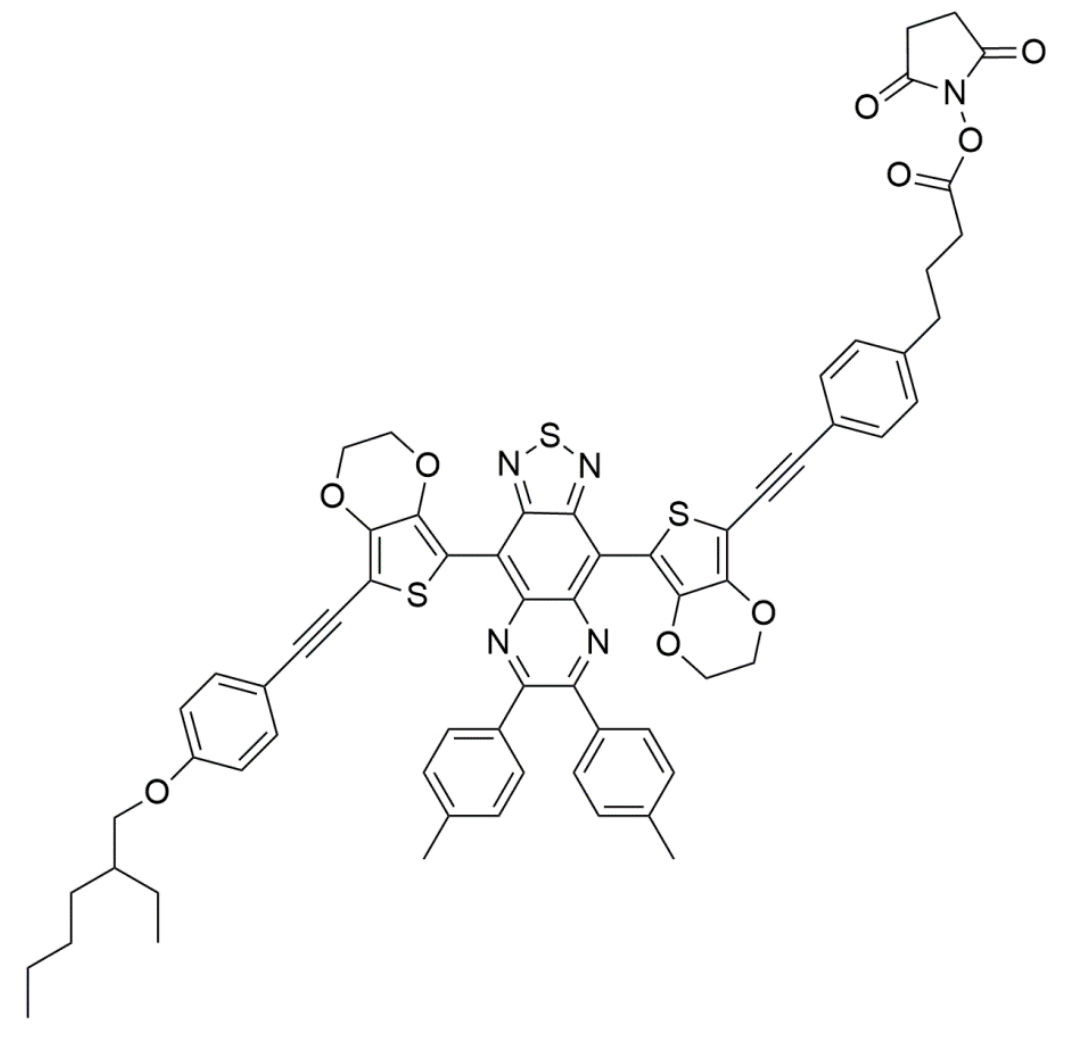

${ }^{13} \mathrm{C}-\mathrm{NMR}$ spectrum of AE800

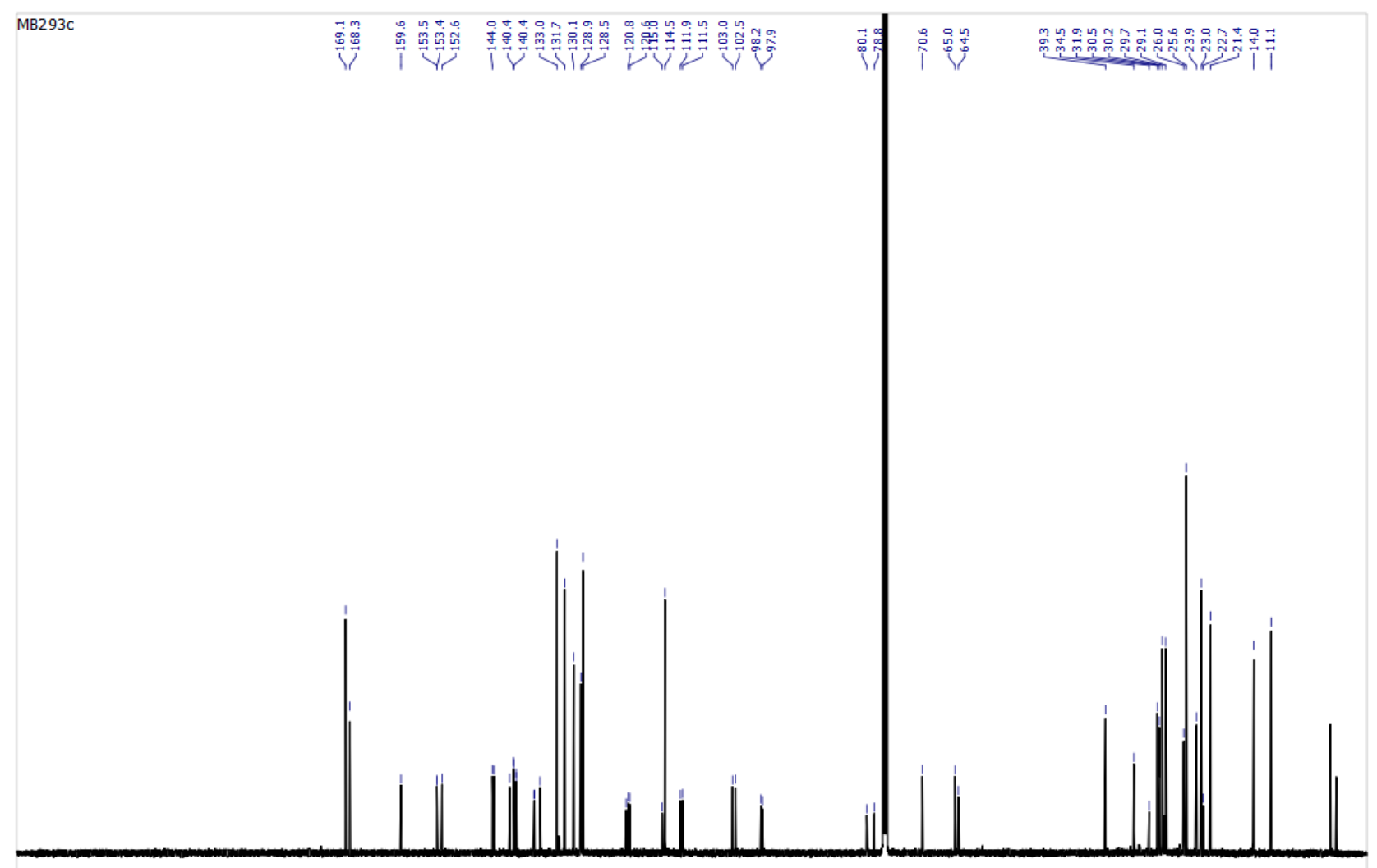

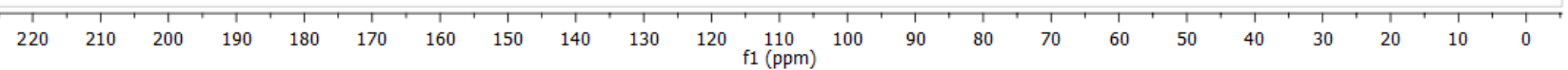


(1) Lo, S.-C., Harding, R. E., Brightman, E., Burn, P. L., and Samuel, I. D. W. (2009) The development of phenylethylene dendrons for blue phosphorescent emitters. J Mater Chem 19, 3213-3227.

(2) Zoombelt, A. P., Fonrodona, M., Wienk, M. M., Sieval, A. B., Hummelen, J. C., and Janssen, R. A. J. (2009) Photovoltaic Performance of an Ultrasmall Band Gap Polymer. Org Lett 11, 903-906.

(3) Uno, T., Takagi, K., and Tomoeda, M. (1980) Synthesis of Bisfurazanobenzo-2, 1, 3-thiadiazole and Related Compounds. Chem Pharm Bull 28, 1909-1912.

(4) Wang, E., Hou, L., Wang, Z., Hellström, S., Mammo, W., Zhang, F., Inganäs, O., and Andersson, M. R. (2010) Small Band Gap Polymers Synthesized via a Modified Nitration of 4,7-Dibromo-2,1,3benzothiadiazole. Org Lett 12, 4470-4473.

(5) Bolognesi, A., DiGianvincenzo, P., Giovanella, U., Mendichi, R., and Schieroni, A. G. (2008) Polystyrene functionalized with EDOT oligomers. European Polymer Journal 44, 793-800.

(6) Mohanakrishnan, A. K., Hucke, A., Lyon, M. A., Lakshmikantham, M. V., and Cava, M. P. (1999) Functionalization of 3,4-ethylenedioxythiophene. Tetrahedron 55, 11745-11754.

(7) Xiang, W., Gupta, A., Kashif, M. K., Duffy, N., Bilic, A., Evans, R. A., Spiccia, L., and Bach, U. (2013) Cyanomethylbenzoic acid: an acceptor for donor-pi-acceptor chromophores used in dye-sensitized solar cells. ChemSusChem 6, 256-60. 